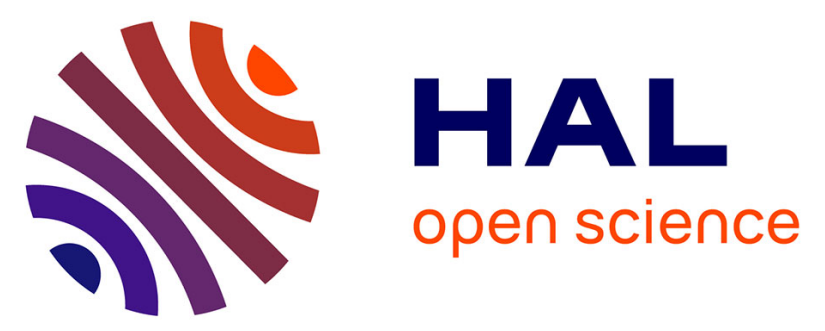

\title{
Microbial functional structure and stable isotopic variation of leptocephali across three current zones in the western South Pacific
}

Leopold Ghinter, Christine Dupuy, Michael J. Miller, Alexandre Carpentier, Christel Lefrançois, Anthony Acou, Jun Aoyama, Mari Kuroki, Camilla Lienart, Shun Watanabe, et al.

\section{To cite this version:}

Leopold Ghinter, Christine Dupuy, Michael J. Miller, Alexandre Carpentier, Christel Lefrançois, et al.. Microbial functional structure and stable isotopic variation of leptocephali across three current zones in the western South Pacific. Progress in Oceanography, 2020, 182, pp.102264. $10.1016 /$ j.pocean.2020.102264 . hal-02518761

\section{HAL Id: hal-02518761}

\section{https://hal-univ-rennes1.archives-ouvertes.fr/hal-02518761}

Submitted on 25 Mar 2020

HAL is a multi-disciplinary open access archive for the deposit and dissemination of scientific research documents, whether they are published or not. The documents may come from teaching and research institutions in France or abroad, or from public or private research centers.
L'archive ouverte pluridisciplinaire $\mathbf{H A L}$, est destinée au dépôt et à la diffusion de documents scientifiques de niveau recherche, publiés ou non, émanant des établissements d'enseignement et de recherche français ou étrangers, des laboratoires publics ou privés. 


\section{Microbial functional structure and stable isotopic variation of leptocephali across three current zones in the western South Pacific}

Leopold Ghinter ${ }^{1,2, *}$, Christine Dupuy, ${ }^{1, *}$, Michael J. Miller ${ }^{3}$, Alexander Carpentier ${ }^{\mathbf{4}}$, Christel Lefrançois ${ }^{1}$, Anthony Acou ${ }^{5}$, Jun Aoyama ${ }^{6}$, Mari Kuroki ${ }^{7}$, Camilla Liénart ${ }^{8}$, Shun Watanabe ${ }^{9}$, Katsumi Tsukamoto ${ }^{3}$, Tsuguo Otake ${ }^{7}$, Eric Feunteun ${ }^{5}$

${ }^{1}$ UMR 7266 LIENSs, Littoral Environnement et Société, 2, rue Olympe de Gouges, 17000 La Rochelle, France

${ }^{2}$ Institut des sciences de la mer à Rimouski (ISMER), Université du Québec à Rimouski (UQAR), 310 allée des Ursulines, Rimouski (Québec, CANADA)

${ }^{3}$ Department of Marine Science and Resources, College of Bioresource Sciences, Nihon University 1866 Kameino, Fujisawa-shi, Kanagawa, 252-0880, JAPAN

${ }^{4}$ EA 7316, Université de Rennes 1, 35042 Rennes Cedex, FRANCE

${ }^{5}$ Museum National d'Histoire Naturelle, BOREA (MNHN, CNRS, Sorbonne Université, IRD, UniCaen, Univ Antilles Guadeloupe), Station Marine de Dinard, CRESCO. 38, rue du port Blanc 35800 Dinard, FRANCE

6International Coastal Research Center, Atmosphere and Ocean Research Institute, The University of Tokyo, Otsuchi, Iwate 028-1102, JAPAN

${ }^{7}$ Department of Aquatic Bioscience, Graduate School of Agricultural and Life Sciences, The University of Tokyo, 1-1-1, Yayoi, Bunkyo, Tokyo 113-8657, JAPAN

${ }^{8}$ Department of Ecology, Environment and Plant sciences, Stockholm University, SWEDEN

${ }^{9}$ Department of Fisheries, Faculty of Agriculture, Kindai University, 3327-204 Nakamachi, Nara, 631-8505, JAPAN

*Co-first author

Address for correspondence: cdupuy@univ-lr.fr 


\section{ABSTRACT}

The ecology of leptocephali remains poorly known but they appear to feed on marine snow that can vary spatially and temporally according to the food web dynamics. This study provided new information about the position of leptocephali within the functional structure of microbial plankton and other food web components of the western South Pacific (WSP) region at a large geographic scale including the New Caledonia, Fiji, and Samoa islands. The hydrographic structure varied with latitude, and nutrient levels were generally low but somewhat variable. Stable isotopic signatures were examined in relation to the 3 current zones of the eastward flowing South Equatorial Countercurrent (SECC; north), the westward South Equatorial Current (SEC; mid-latitudes), and the eastward South Tropical Countercurrent (STCC; south), and all zones were found to be primarily based on a heterotrophic planktonic functioning that were co-limited by inorganic nitrogen and phosphorus, with biomasses of planktonic groups varying with depth. Isotopic signatures of leptocephali were compared to the signatures of other mesozoplankton, micronekton, and Trichodesmium components of the food web, and in relation to the signatures of particulate organic matter (POM) that varied among the 3 collection depths. The isotopic signatures of six taxa of leptocephali, other taxonomic groups and POM showed interesting variability according to latitude and among some stations. The presence of Trichodesmium at the surface in the STCC zone influenced the isotopic signatures of POM and thus the signatures of leptocephali. The signatures of leptocephali were therefore linked with the overall food web and were consistent with the larvae feeding on marine snow components of POM. The two apparent groups of leptocephali with different isotopic signatures that have also been observed in other oceanic areas may be explained by feeding behavior at different depths or on different types of marine snow.

Key words: Western South Pacific, Leptocephali, meso-macro-zooplankton, micronekton, POM, isotopic signature, microbial loop

\section{Highlights}

- Western South Pacific microbial biomass/function and stable isotopes were examined

- Primary producers, whatever the depth, were N-P co-limited

- All zones were based on a heterotrophic planktonic functioning

- Stable isotope signatures of leptocephali, POM and other components of the food web were analyzed

- POM signatures varied with depth and latitude, influencing all taxonomic groups

- The presence of Trichodesmium may contribute to low southern $\delta^{15} \mathrm{~N}$ values 


\section{Introduction}

Leptocephali are the highly transparent leaf-like larvae of anguilliform fishes and their relatives of the super-order Elopomorpha (Smith, 1989; Inoue et al., 2004), which contains more than 800 species (Nelson, 2006). The order Anguilliformes is composed of 15 families and 3 suborders Anguilloidei, Congroidei and Muraenoidei. This diversity is reflected by a widespread distribution, with anguilliforms being found in almost all oceans and habitats: from southern and northern hemisphere temperate zones to tropical latitudes (Castle, 1984; Böhlke, 1989a, b). This widespread distribution is possibly due to a diversity of ecological traits, including diadromous anguillid eel and migratory and sedentary marine eel life histories. Adults may be benthic in deeper waters (Nettastomatidae, Synaphobranchinae) or mesopelagic offshore (Serrivomeridae, Nemichthydae) and many species live in coastal or continental shelf areas (Muraenidae, Congridae, Ophichthidae) (Miller and Tsukamoto, 2004). Among them, the Anguillidae forms a unique catadromous family whose leptocephali use offshore areas for development and are transported to their recruitment areas by ocean currents (Miller and Tsukamoto, 2017). Despite this wide range of juvenile and adult habitats, all anguilliform larvae live together in the upper few hundred meters of the ocean (Castonguay and McCleave, 1987; Miller, 2009; Onda et al., 2017).

Leptocephali are likely present throughout oligotrophic tropical and sub-tropical oceanic areas (Miller et al., 2019a) where primary production and the amount of trophic resources available are much lower in comparison to temperate areas (McGowan, 1974), but they also occur along continental shelves where productivity is higher (Miller, 2009). At least some species make diel vertical migrations in the open ocean from within the upper $100 \mathrm{~m}$ at night to as deep as about $250 \mathrm{~m}$ during the day (Castonguay and McCleave, 1987; Otake et al., 1998). Diel vertical migration is a ubiquitous behavior of organisms in pelagic ecosystems (Hays, 2003). It allows species to feed in the upper food-rich layers of the water column during the night and to reduce the risk of visual predation occurring in the illuminated upper layer in daylight (Tarling, 2003). The degree to which leptocephali use these behaviors in each area is unknown, and some species can be caught at the surface in neuston nets (Miller et al., 2006a; Ross et al., 2007; Miller, 2009; Quattrini et al., 2019).

The yolk reserves of the newly hatched larvae, referred to as preleptocephali, of anguillid eels are consumed within one to two weeks after hatching, then larvae actively feed in their environment (Otake et al., 1995; Tanaka et al., 1995). However, which materials in the photic zone such as phytoplankton and zooplankton or decaying organic matter leptocephali use as a food resource has remained a mystery for many years. Like many fish larvae (Last, 1978; Post 
and Kitchell, 1997), mesozooplankton ( $>0.2 \mathrm{~mm}$ ) could be a food source for leptocephali, but none of these organisms were observed in leptocephalus gut contents..

However, studies that directly analyzed the stomach contents of leptocephali and found a variety of materials including zooplankton fecal pellets and discarded appendicularian (larvacean) houses (Otake et al., 1993; Mochioka and Iwamizu, 1996). Ciliates were also reported to be present (Otake, 1990; Govoni, 2010). Similar materials were also seen in photographic studies of leptocephalus gut contents, along with the typical amorphous material that is present in their guts (Miller et al., 2011, 2019b). These, which coincide with the observations of Tomoda et al. $(2015,2018)$ and Chow et al. (2010), are all consistent with leptocephali ingesting POM-like materials including marine snow. The latter host a very rich and abundant flora and fauna (Alldredge and Silver, 1988; Shanks and Walters, 1997; Kiørbe, 2000; Bochdansky et al., 2017).

Studies using stable carbon and nitrogen isotopic signatures of their body tissues indicated that leptocephali feed at a low level within the food web (Otake et al., 1993; Kimura et Tsukamoto, 2006; Miyazaki et al., 2011; Feunteun et al., 2015; Liénart et al., 2016; Quattrini et al., 2019). Their low trophic position was also confirmed using amino acid isotope analyses (Miller et al., 2013b). Other studies used DNA sequencing techniques with the gut contents of small leptocephali and found that a broad range of DNA sequences, including from bacteria, fungi, radiolarians, crustaceans, chaetognaths and gelatinous zooplankton were contained in their intestinal contents (Riemann et al., 2010; Ayala et al., 2018). However, tissue materials of all of those types of living or dead planktonic organisms can aggregate into POM and marine snow (Alldredge and Silver, 1988; Shanks and Walters, 1997; Kiørboe, 2000).

Therefore, although small leptocephali may be able to directly ingest some types of small organisms, the primary hypothesis about the food source of leptocephali is that they feed on marine snow. Marine snow is omnipresent and very abundant in the ocean (Alldredge, 1972, 1976; Alldredge and Silver, 1988; Turner, 2002; Pilskaln et al., 2005) and would be a readily available food source for leptocephali. Due to the oligotrophic status of tropical ocean waters, marine snow represents a major component of the pelagic ecosystem and is also the main trophic link between the photic and aphotic zones as it sinks to the ocean floor (Fowler and Knauer, 1986). These particles are colonized and enriched by a succession of bacterial communities during their fall through the water column (Pomeroy and Deibel, 1980), representing a trophic source for many grazers and are an alternative to the herbivorous food web generally occurring in more eutrophic waters (Kiørboe, 2001, 2011; Schnetzer and Steinberg, 2002; Simon et al., 2002). Marine snow particles have also been recently found to 
be colonized by the less-well known heterotrophic stramenopile protists of the Labyrinthulomycetes (Li et al., 2013; Bochdansky et al., 2017), which appear to have been present in the gut contents of leptocephali in the Sargasso Sea (Miller et al., 2019b).

There is still little direct evidence of what type of marine snow might be ingested or what components of it are being assimilated by leptocephali (Miller, 2009; Feunteun et al., 2015; Liénart et al., 2016). It is also unclear whether leptocephali are feeding specialists or if any type of available particulate matter, such as marine snow, is sufficient as a food source (Miller, 2009). Feunteun et al. (2015) suggested the interspecific variety of observed head and jaw shapes (Böhlke, 1989a, b; Miller and Tsukamoto, 1994; Miller, 2009) might be related to feeding on different types of POM including marine snow. That study also found that there were two groups of isotopic signatures for species that reach large body sizes and those that do not (Feunteun et al., 2015). Those differences might be caused by the depths where they feed in the water column, or by the larvae consuming different types of POM.

Recent studies that investigated the possible contribution of marine snow to the diet of leptocephali species have analyzed POM filtered from water that was collected at various depths with Niskin bottles to evaluate the role of POM using $\delta^{15} \mathrm{~N}$ and $\delta^{13} \mathrm{C}$ isotopic ratios (Feunteun et al., 2015) or combined with fatty acids (Liénart et al., 2016). Both studies showed gaps between the POM baseline signatures and those of leptocephali that did not show clear linkages with the POM signatures. Various possible reasons for this were discussed that include leptocephali selecting specific types of POM, or soluble fractions of POM not being retained during the filtration process. The study of Liénart et al. (2016) found latitudinal differences in the isotopic signatures across the latitudes of the western south Pacific (WSP). The fatty acid compositions of leptocephali were also studied from across the continental slope of the northwest Australia region (Deibel et al. 2012) as part of the effort to understand leptocephalus ecology.

Studies on plankton in the WSP focused on the nutrient cycle and nitrogen fixation by diazotrophic microorganisms (Campbell et al., 2005; Barboza Tenório et al., 2018; Knapp et al., 2018; Leblanc et al., 2018; Moutin et al., 2018; Van Wambeke et al., 2018), picophytoplankon distribution (Blanchot and Rodier, 1996; DiTullio et al., 2003; Grob et al., 2007; Rii et al., 2016; Zhang et al., 2008) and mesozooplankton and micronekton distribution (Hannides et al., 2013; Menkes et al. 2015; Carlotti et al., 2018), but none have attempted to examine planktonic microbial functional structure and stable isotopic variation of leptocephali. 
The present study builds on the Liénart et al. (2016) stable isotope and fatty acid composition study in the WSP by expanding the range of taxa of leptocephali used and by analyzing the other organism components in relation to POM collected from different depths. The aims of this study were: 1) to reexamine the position of leptocephali within the planktonic food web of the WSP region at a large geographic scale. To this end, we performed an isotopic study of a wide diversity of organisms including leptocephali, to examine variations among leptocephali families and to evaluate the possible role of POM as a food source according to the characteristics of the environment (depth, latitude); and 2) analyze the living parts of the POM (prokaryotes and eukaryotes) that are a part of marine snow, and to consider the functional structure of the microbial loop, possibly limited by nutrients and controlled by grazing. To this end, we performed onboard grazing and nutrient enrichment experiments.

\section{Material and methods}

\subsection{Study area and hydrographic parameters}

The study was conducted in the intertropical region of the WSP that is somewhat unique in having numerous islands and atolls surrounded by deep pelagic areas (Fig. 1). The ocean currents and general hydrographic structure of the WSP have been overviewed previously (Miller et al., 2006b; 2009; Ganachaud et al., 2014), but one of the main features is the westward flowing South Equatorial Current (SEC, from $5^{\circ} \mathrm{N}$ and $20^{\circ} \mathrm{S}$ of latitude). In between the two latitudinal zones of the SEC, there is a narrow seasonally occurring eastward South Equatorial Counter Current (SECC from about 5 to $10^{\circ} \mathrm{S}$ ) (Kessler and Taft, 1987; Chen and Qiu, 2004) (Fig. 1). To the south of the SEC there is eastward flow that has been referred to as the South Tropical Counter Current (STCC).

Sampling was made during Leg 2 of the KH-13-2 research cruise of the R/V Hakuho Maru from 4-24 February 2013. A total of 34 stations were sampled mostly at every $2^{\circ}$ of latitude intervals in the region from New Caledonia to east of Fiji and Samoa $\left(5^{\circ} \mathrm{S}-0^{\circ}, 165^{\circ} \mathrm{E}-170^{\circ} \mathrm{W}\right.$, Fig. 1). The average depth of the ocean floor at the sampling stations ranged from 1370 to $5537 \mathrm{~m}$. Salinity and temperature profiles were performed using a conductivity-temperaturedepth (CTD) and oxygen probes (Sea-Bird SBE 9) from the surface to $500 \mathrm{~m}$ depths. The fluorescence profiles of the water column observed during the CTD down-casts were evaluated to determine the depths of the maximum in situ fluorescence for water sampling there during the up-casts. Water samples from subsurface $(5 \mathrm{~m})$, the maximum fluorescence depth (at 80-145 m, depending on station) and at 200-260 m depths (depending on station) were collected using $12 \mathrm{~L}$ Niskin bottles. Water samples, from the maximum fluorescence 
depth were filtered immediately for analyzing dissolved inorganic nutrients [nitrate $\left(\mathrm{NO}_{3}\right)$, nitrite $\left(\mathrm{NO}_{2}\right)$, ammonium $\left(\mathrm{NH}_{4}\right)$, silicate $\left(\mathrm{Si}(\mathrm{OH})_{4}\right)$ and phosphate $\left.\left(\mathrm{PO}_{4}\right)\right]$, using $\mathrm{GF} / \mathrm{F}$ filters $\left(0.7 \mu \mathrm{m}\right.$, Whatman, $47 \mathrm{~mm}$ diameter). Filtrates were stored at $-20^{\circ} \mathrm{C}$ for $\mathrm{NO}_{3}, \mathrm{NO}_{2}, \mathrm{NH}_{4}$, and $\mathrm{PO}_{4}$, and $4{ }^{\circ} \mathrm{C}$ for $\mathrm{Si}(\mathrm{OH})_{4}$ until analysis with a Skalar autoanalyzer (Strickland and Parsons, 1972).

\subsection{Determining composition of particulate organic matter (POM)}

\subsubsection{Sampling design}

POM, defined as organic particles $>0.2 \mu \mathrm{m}$, is composed of a mixture of living microorganisms and decaying organic matter including marine snow, so our objective was to evaluate many aspects of the overall community that can contribute to the marine snow that leptocephali might consume. We analyzed the abundance and biomass of heterotrophic prokaryotic and eukaryotic nanoplankton (defined as $0.2-2 \mu \mathrm{m}$ and 3-20 $\mu \mathrm{m}$ respectively) (see section 2.2.3), phytoplankton (chlorophyll a biomass as a proxy of phytoplankton biomass) by size classes (picophytoplankton: $<3 \mu \mathrm{m}$, nanophytoplankton: 3-20 $\mu \mathrm{m}$ and microphytoplankton: $>20 \mu \mathrm{m}$ ) directly from water samples or using different filter pore sizes (see section 2.2.4). The isotopic signature of POM was also analyzed from filtered water samples. Samples were obtained with Niskin bottles during the CTD casts at 13 stations (Fig. 1) and at the same 3 depths described above. Stations were chosen to cover each general area of the study region and of the latitudinal ranges that correspond to the main current systems.

\subsubsection{Samples of total POM for isotopic analysis}

At each station, 6 to $14 \mathrm{~L}$ of water was filtered depending on visual estimation of the concentration of POM. The water was filtered under $<10 \mathrm{~mm} \mathrm{Hg}$ vacuum pressure using glass fiber filters $\left(\mathrm{GF} / \mathrm{F}, 47 \mathrm{~mm}\right.$ diameter, $0.7 \mu \mathrm{m}$ mesh) that were pre-combusted $\left(490^{\circ} \mathrm{C}, 2\right.$ h) to eliminate organic carbon content. Filters containing POM samples were dried at $60^{\circ} \mathrm{C}$ for $12 \mathrm{~h}$ and analyzed for their stable isotopic content with a mass spectrometer (see section 2.5).

\subsubsection{Abundance/biomass of pico- and nano-plankton}

Five ml water samples were fixed with $2 \%$ formaldehyde and then frozen in liquid $\mathrm{N}_{2}$ for analysis of heterotrophic picoplankton (e.g. bacteria). Afterwards, samples were stored at $80^{\circ} \mathrm{C}$ until enumeration. Each sample was analyzed for $30 \mathrm{~s}$ at low flow speed with a FacsCanto II cytometer (3-laser, 8-color (4-2-2), BD Biosciences) equipped with a $20 \mathrm{~mW}$ 
$488 \mathrm{~nm}$ coherent sapphire solid state blue laser. Data were acquired using DIVA software provided by BD-Biosciences.

For the enumeration of nanoplankton (nanoflagellates=NF; comprising pigmented (PNF) and heterotrophic (HNF) nanoflagellates), $30 \mathrm{~mL}$ of seawater was preserved with $3 \mathrm{~mL}$ of $0.2 \mu \mathrm{m}$ filtered paraformaldehyde ( $2 \%$ final concentration) and placed at $4{ }^{\circ} \mathrm{C}$ until analysis. Samples were concentrated to $10 \mathrm{~mL}$ with a filtration tower mounted with $0.8 \mu \mathrm{m}$ pore size black polycarbonate filters (Nucleopore) and stained with DAPI $\left(2.5 \times 10^{-4} \mathrm{~g} \mathrm{~L}^{-1}\right.$ final concentration). Enumeration of stained nanoplanktonic cells was performed using an epifluorescence microscope (Zeiss Axioskop, x 1000 magnification). This method permitted distinguishing PNF from HNF by repeatedly interchanging the filter sets of the microscope (Caron, 1983): phototrophic cells (crimson under UV $365 \mathrm{~nm}$ excitation and red colored under green 450-490 nm excitation) and heterotrophic cells (blue under UV excitation and invisible under green excitation) were enumerated separately. The abundance of each group was converted to carbon biomass $\left(\mu \mathrm{g} \mathrm{C} \mathrm{mL}^{-1}\right.$ ) according to the conversion factor used in Feunteun et al. (2015).

\subsubsection{Phytoplankton biomass by size classes}

The phytoplanktonic community was also studied using the proxy of biomass of chlorophyll $a(\operatorname{chl} a)$. Water samples $(100$ to $6000 \mathrm{~mL})$ were filtered in order to sort three functional classes: picophytoplankton $(<3 \mu \mathrm{m})$, nanophytoplankton $(3-20 \mu \mathrm{m})$ and microphytoplankton $(>20 \mu \mathrm{m})$, using three successive filtrations on three membranes with different porosity (Whatman $\mathrm{GF} / \mathrm{F}(0.7,3,20 \mu \mathrm{m}$ of porosity $-25 \mathrm{~mm}$ diameter). Each filter was stored at $-20^{\circ} \mathrm{C}$ until analysis. Laboratory extraction used a Turner TD 700 Fluorimeter and followed the protocol proposed by Lorenzen (1967) and Aminot and Kérouel (1982). Chlorophyll $a$ biomass was expressed as $\mu \mathrm{g} \mathrm{L}^{-1}$ and converted into carbon biomass (50 $\mu \mathrm{g} \mathrm{C}$ corresponding to $1 \mu \mathrm{g} \operatorname{chl} a$ ).

\subsection{On board experiments on microbial loop functioning}

Water samples were taken from the depth of maximum fluorescence (between 80-145 m) at stations 39, 41, 47, 49, 51 and 55 (Fig. 1), with a minimum of one station per current region (SEC, SECC and STCC). Originally 11 grazing experiments were attempted (3 in STCC, 5 in SEC and 3 in SECC). Unfortunately, 5 of them did not work, due to a decrease of all the microorganisms in the experiments, so the final number of grazing experiments was 6 (1 in STCC, 4 in SEC and 1 in SECC, Fig. 1). These experiments were conducted according to the 
methodology developed by Bouvy et al. (2011). Two bioassay series were conducted to compare the functioning and the responses of the microbial loop to inorganic enrichment (adding nutrients) with $100 \%$ of predators (nanoplankton, potential predators, using $<10 \mu \mathrm{m}$ filtered water) for the grazing rate measurement and with $1 \%$ of predators (using $99 \%$ of 0.22 $\mu \mathrm{m}$-filtered water and $1 \%$ of $<10 \mu \mathrm{m}$-filtered water) for the growth rate measurement. Each experimental group was duplicated in 2x100 mL Whirlpack polyethylene sterile bags, which allow the transmission of $70 \%$ UV radiation, and incubated for $24 \mathrm{~h}$ on the deck of the ship with continuous renewal of seawater pumping to maintain a constant temperature in the bath. At time zero (t0), inorganic nitrogen ( $\mathrm{N}$ : mixture of $5 \mu \mathrm{M}$ as $\mathrm{NH}_{4} \mathrm{Cl}$ and $5 \mu \mathrm{M}$ as $\mathrm{NO}_{3}$ ) and inorganic phosphorus ( $\mathrm{P}: 1 \mu \mathrm{M}$ as $\mathrm{NaH}_{2} \mathrm{PO}_{4}$ ) were added alone or combined: $+\mathrm{N},+\mathrm{P},+\mathrm{NP}$; nothing was added to the controls. In all experiments, subsamples were removed at time zero (t0) and after $24 \mathrm{~h} \mathrm{(t24)} \mathrm{incubation} \mathrm{to} \mathrm{measure} \mathrm{the} \mathrm{picoplankton} \mathrm{(picophytoplankton} \mathrm{and}$ heterotrophic picoplankton) abundance. In addition to picoplankton, nanoplankton abundance was measured in the $100 \%$ predator experiments. The picoplankton growth rates $(\mu)$ in each duplicate were calculated as:

$\mu=(\ln \mathrm{N} 24-\ln \mathrm{N} 0) / \mathrm{t}$, where $\mathrm{t}$ was the incubation time and N24 and N0 were the picoplankton concentration at the end and at the beginning of the incubation time, respectively. The grazing rates ( $g$ expressed in day $^{-1}$ ) was calculated using the same equation in the presence of predators (see Bouvy et al., 2011).

\subsection{Sampling leptocephali, meso-macro-zooplankton, micronekton and primary producers}

Leptocephali, meso-macro-zooplankton $(0.2-20 \mathrm{~mm})$ and micronekton $(20-200 \mathrm{~mm})$ were collected at each station using an Isaacs-Kidd Midwater Trawl (IKMT) with an $8.7 \mathrm{~m}^{2}$ mouth opening and $0.5 \mathrm{~mm}$ mesh. In order to limit sampling bias due to daytime leptocephali net avoidance (Miller and McCleave, 1994; Miller et al., 2006b, 2013a) and their diel vertical distribution (Castonguay and McCleave, 1987), two strategies of trawl deployment were used: during the day, a one hour oblique tow was conducted from the surface to $200 \mathrm{~m}$ at each station, whereas during the night a step tow sampling every $50 \mathrm{~m}$ from the surface to $150 \mathrm{~m}$ was made.

Identification of leptocephali to the family, and when possible the genus levels, was conducted on board according to the criteria summarized in Tabeta and Mochioka (1988), Böhlke (1989a, b) and Miller and Tsukamoto (2004). Among the total number of leptocephali captured during the survey $(\mathrm{N}=538)$, we selected 91 leptocephali (17\% of the total number) that were preserved in $99 \%$ ethanol for isotopic analysis from 16 stations (Fig. 2) belonging to 
the 4 most abundant families: Serrivomeridae $(\mathrm{N}=19$; Length Range $(\mathrm{LR})=[6.0-154.4 \mathrm{~mm}]$, Length Mean $(\mathrm{LM}) \pm \mathrm{SD}=49.4 \pm 31.2 \mathrm{~mm})$, Muraenidae $(\mathrm{N}=28 ; \quad \mathrm{LR}=[23.2-83.0 \mathrm{~mm}], \mathrm{LM}=$ $51.8 \pm 13.9 \mathrm{~mm})$, Congridae $(\mathrm{N}=15 ; \mathrm{LR}=[53.4-81.4 \mathrm{~mm}], \mathrm{LM}=81.4 \pm 53.4 \mathrm{~mm})$ and Nemichthyidae including Nemichthys $(\mathrm{N}=22 ; \mathrm{LR}=[37.2-259.0 \mathrm{~mm}], \mathrm{LM}=123.7 \pm 73.9 \mathrm{~mm})$ and Avocettina $(\mathrm{N}=31 ; \mathrm{LR}=[20.3-223.0 \mathrm{~mm}], \mathrm{LM}=113.7 \pm 60.1 \mathrm{~mm})$. Among the Congridae, Ariosoma sp. $(\mathrm{N}=3 ; \mathrm{LR}=[77.2-220.8 \mathrm{~mm}], \mathrm{LM}=143.3 \pm 72.5 \mathrm{~mm})$ were separated from other Congridae (genus Conger, Gnathophis, Gorgasia and Bathycongrus) because they are a different subfamily, and because Ariosoma leptocephali can have different isotopic signatures than other species of the Congridae and other families that also have smaller maximum lengths (Miyazaki et al., 2011; Feunteun et al., 2015). We also used the two morphologically distinct genera of Nemichthyidae: Avocettina sp. $(\mathrm{N}=19)$ and Nemichthys sp. $(\mathrm{N}=10)$ for comparison of isotopic signatures. Not all taxa of leptocephali were evenly distributed among latitudes, which contributed to the imbalance of specimens among latitudes and sample sizes of some taxonomic groups (see Miller et al., 2006b, Liénart et al., 2016).

Meso- and macro-zooplankton were identified to class, subclass, order, family or species (copepods to genus or species when it was possible) for euphausids $(\mathrm{N}=26)$, chaetognaths $(\mathrm{N}$ =7), cephalopods $(\mathrm{N}=8)$, polychaetes $(\mathrm{N}=5)$ and copepods $(\mathrm{N}=49)$. Euphausids were separated into two groups according to their size $(<10 \mathrm{~mm}$ and $>10 \mathrm{~mm})$. Copepods were composed of Calanoidae that included the species Metridia venusta $(\mathrm{N}=9)$, Pleuromamma abdominalis $(\mathrm{N}=10)$, Pleuromamma xiphias $(\mathrm{N}=9)$ and the genera Candacia $(\mathrm{N}=8)$, Temora $(\mathrm{N}=2)$ and Anomalocera $(\mathrm{N}=1)$. Among micronekton, 3 groups of fish were considered: family Myctophidae $(\mathrm{N}=12)$, tuna larvae (Scombridae) $(\mathrm{N}=3)$ and unidentified fish larvae $(\mathrm{N}=16)$. One genus of primary producer, a cyanobacteria Trichodesmium $s p$. $(\mathrm{N}=$ 2) that formed small aggregates, was collected from two IKMT station samples when it was present, and it was isolated under a binocular microscope for collection. All samples were stored in $70 \%$ ethanol for further isotopic analysis.

\subsection{Stable isotope analyses}

Filters containing POM were dried at $60^{\circ} \mathrm{C}$ for $12 \mathrm{~h}$, and plankton (e.g. copepods, cephalopods...), micronekton and small fish were rinsed 3 times with distilled water and lyophilized before analysis. These organisms were analyzed without any dissection, except for big euphausids for which shell and head were removed. Plankton samples were not decarbonated or delipidated because similar studies did not find any significant changes in $\delta^{13} \mathrm{C}$ and $\delta^{15} \mathrm{~N}$ ratios before and after acidification (Bode et al., 2004; Chouvelon et al., 2014) 
or the delipidation processes (Bodin et al., 2007; Chouvelon et al., 2014). Small pelagic fishes and larvae were used entirely, while only muscles were sampled in larger individuals. Leptocephali bodies without the head were analyzed, and were not decarbonated or delipidated because this appears not necessary for muscle (Pinnegar and Polunin, 1999). For whole individuals, preliminary tests did not show significant differences between treated and untreated samples (Bourillon, comm.pers).

Samples were analyzed with a Thermo Scientific Delta V Advantage mass spectrometer coupled to a Thermo Scientific Flash EA1112 elemental analyser to determine their carbon and nitrogen stable isotope contents. The carbon and nitrogen isotope ratios were reported according to the standard delta notation $\delta^{13} \mathrm{C}$ and $\delta^{15} \mathrm{~N}$, where: $\delta \mathrm{X}=\left[\left(\mathrm{R}_{\text {Sample }} / \mathrm{R}_{\text {Reference }}\right)-1\right] \times$ 1000 , where $\mathrm{X}=\delta^{13} \mathrm{C}$ or $\delta^{15} \mathrm{~N}$ and $\mathrm{R}$ is the ratio ${ }^{13} \mathrm{C}:{ }^{12} \mathrm{C}$ or ${ }^{15} \mathrm{~N}:{ }^{14} \mathrm{~N}$ in the sample and in the reference material. References are Vienna Pee Dee Belemnite (VPDB) (Craig, 1957) for C and to atmospheric nitrogen for N (Peterson and Fry, 1987; Ehleringer and Rundel, 1989) and results are expressed in units of $\%$ \pm standard deviation (SD).

\subsection{Statistical analysis}

Before comparison analysis, data were evaluated for homoscedasticity (Levene-test) and normality of distribution (Shapiro-Wilk-test). If the data did not meet the assumptions, they were $\log$ or exponential transformed. When the assumptions were met, comparisons of two averages were performed using t-tests and comparison of more than two variances with ANOVA followed by post-hoc Tukey tests when ANOVA were significant $(p<0.05)$. In the case where assumptions were not met, non-parametric tests were used: two samples were compared with non-parametric Mann-Whitney-tests (MW), and more than two samples were compared with Kruskal-Wallis-test (KW) followed by a multiple comparison test (bilateral) when KW were significant $(p<0.05)$. All averages were expressed with their standard deviation $( \pm \mathrm{SD})$. Statistical analyses were performed with Statistica software (Statsoft v.6.1, Tulsa, OK, USA). Cartography was made using "R" software and the package "map" and "marmap" (Fig 1.a).

\section{Results}

\subsection{Hydrographic structure}

Hydrographic sections constructed from the CTD casts along or near $180^{\circ}$ (middle line of stations) and $170^{\circ} \mathrm{W}$ (eastern line of stations) (Fig. 1) showed the typical structure of temperature and salinity that occurs in the WSP (Miller et al., 2006b; Schabetsberger et al., 
2016). The warm water of the upper mixed layer $\left(28-30^{\circ} \mathrm{C}\right)$ was deeper in the north $(\sim 100 \mathrm{~m})$ and then steadily became shallower to the south, with surface temperatures of $26^{\circ} \mathrm{C}$ at the southernmost stations at $24^{\circ} \mathrm{S}$ (Figs. 3a, e). Temperatures at depths of around $250 \mathrm{~m}$, which is likely to be the approximate maximum depth reached by leptocephali during the day if they vertically migrate deeper from the upper $100 \mathrm{~m}$ where they reside at night (Castonguay and McCleave, 1987), were $18-19^{\circ} \mathrm{C}$. The deeper mixed layer in the north included the lower salinity water of the "Fresh Pool" that is typically present there, with salinities of about 34.235.5 (Figs. 3b, f). Deeper, at about 75-200 m the subsurface layer of Subtropical Underwater (STUW) was present (see Schabetsberger et al., 2016) that had maximum core-area salinities of 36.2 at $180^{\circ}$ and 36.3 at $170^{\circ} \mathrm{W}$. This water forms at the surface through evaporation farther to the east and is subducted into the thermocline as it moves to the west.

\subsection{Chemical and biological water mass parameters}

Average nutrient concentrations were generally low, but typical of tropical marine waters (Table 1). All nutrients, except $\mathrm{NH}_{4}$, which had less variability between the current zones, were higher in the SECC than SEC and STCC. However, concentrations of $\mathrm{NO}_{3}$ ranged from 3.5 to $155.3 \mu \mathrm{g} \mathrm{NO}_{3} \mathrm{~L}^{-1}$ and were variable in the SEC stations (range 3.5-45.3 $\mu \mathrm{g} \mathrm{NO}_{3} \mathrm{~L}^{-1}$ ) and the SECC (range 4.7-155.3 $\mu \mathrm{g} \mathrm{NO}_{3} \mathrm{~L}^{-1}$ ). Concentrations of $\mathrm{NO}_{2}$ ranged from 0 to $19.1 \mu \mathrm{g}$ $\mathrm{NO}_{2} \mathrm{~L}^{-1}$ and were variable in all the current zones. Concentrations of $\mathrm{PO}_{4}$ ranged from 27.1 to $77.8 \mu \mathrm{g} \mathrm{PO}_{4} \mathrm{~L}^{-1}$ and were variable within the SECC (range 27.1-77.8 $\mu \mathrm{g} \mathrm{PO}_{4} \mathrm{~L}^{-1}$ ). Silicate concentrations ranged from 61.2 to $512.6 \mu \mathrm{g} \mathrm{Si}(\mathrm{OH})_{4} \mathrm{~L}^{-1}$ and were variable in all the currents, with maximum variability occurring in the SEC (range 63.9 to $512.6 \mu \mathrm{g} \mathrm{Si}(\mathrm{OH})_{4} \mathrm{~L}^{-1}$ ). Station 63 at the eastern side of the SECC zone had lower concentrations of all parameters compared to the 2 stations to the east, and particularly for $\mathrm{NO}_{3}$ and $\mathrm{NO}_{2}$. Station 49 in the north-central SEC zone also had some lower nutrient values. Station 39 to the east of Vanuatu had an unusually high $\mathrm{Si}(\mathrm{OH})_{4}$ value $\left(512.6 \mu \mathrm{g} \mathrm{L}^{-1} ; 137.5 \mu \mathrm{g} \mathrm{L}^{-1}\right.$ maximum for all other stations).

Maximum fluorescence of the chlorophyll occurred at depths of about $100 \mathrm{~m}$ across the $180^{\circ}$ transect but the maximum values became lower and slightly deeper in the southern half of the $170^{\circ} \mathrm{W}$ transect in the east (Figs. 3c, g). The exact structure and variability of the chlorophyll maximum layer across these latitudes could not be observed because the CTD stations were too far apart, however vertical profiles for each CTD stations were available (vertical lines, Fig. 3). Fluorescence values were consistently lower in the southern half of the eastern most $170^{\circ} \mathrm{W}$ transect. 
Oxygen concentration patterns differed from other parameters. A layer of highest concentrations occurred in the south at depths just above the chlorophyll maximum. However, this structure almost disappeared in the far north (Figs. 3d, h). The lowest oxygen levels occurred deeper than 250-300 $\mathrm{m}$ in the northern half of the section below the STUW.

Planktonic organisms from POM were separated by size groups (Fig. 4). POM was generally dominated by heterotrophic picoplankton (e.g. bacteria; significantly higher than other 4 groups; $\mathrm{K}-\mathrm{W}$ test, $\left.\mathrm{H}_{(4, \mathrm{~N}=225)}=119.4, \mathrm{p}<0.001\right)$ that accounted for 50 to $90 \%$ of the biomass, followed by heterotrophic nanoflagellates (5-27\%) and the three other size groups representing less than $15 \%$ (picophytoplankton (0-15\%), nanophytoplankton $(0.4-12 \%)$, and microphytoplankton $(0-4 \%)$. Total biomass at each station was not significantly different according to currents $\left(\mathrm{K}-\mathrm{W}\right.$ test, $\left.\mathrm{H}_{(2, \mathrm{~N}=225)}=0.67, \mathrm{p}=0.71\right)$, but significantly differed according to depths $\left(\mathrm{K}-\mathrm{W}\right.$ test, $\left.\mathrm{H}_{(4, \mathrm{~N}=225)}=40.56, \mathrm{p}<0.001\right)$. At the deepest layer $(200-260 \mathrm{~m})$, planktonic biomass was lower than at the shallower depths (all comparison tests: $\mathrm{p}<0.001$ ). However, the composition of planktonic organisms changed according to the depths. At surface $(5 \mathrm{~m})$, only the heterotrophic picoplankton dominated with all other groups having low concentrations (Multiple comparison test, $\mathrm{p}<0.01$ ). At maximum fluorescence depth (80-145 m), heterotrophic picoplankton followed by heterotrophic nanoflagellates were dominant and microphytoplankton showed the lowest concentration (Multiple comparison test, $\mathrm{p}<0.001)$. At the deepest layer, heterotrophic picoplankton followed by heterotrophic nanoflagellates were also dominant but the three other groups were almost absent (Multiple comparison test, $\mathrm{p}<0.05)$.

\subsection{Microbial loop functioning}

Growth and grazing rates were assessed for picophytoplankton and heterotrophic picoplankton (Figs. 5,6) in water samples collected in the 3 current zones after nutrients were added or not. In the control, picophytoplankton net growth rate was negative or low, ranging from $-2.1 \pm 2.6$ day $^{-1}$ in the SEC to $0.43 \pm 0.60$ day $^{-1}$ in the STCC (Fig. 5). Grazing rates on picophytoplankton ranged from no grazing in the SECC to $1.4 \pm 1.3$ day $^{-1}$ in the SEC (Fig. 6). Net growth rates of heterotrophic picoplankton were higher and less variable than for picophytoplankton, and ranged from $3.9 \pm 0.01$ day $^{-1}$ in the STCC to $5.2 \pm 0.008$ day $^{-1}$ in the SECC (Fig. 5). The grazing rate on heterotrophic picoplankton ranged from $3.4 \pm 0.03$ in the SECC to $4.3 \pm 0.55$ day $^{-1}$ in SEC (Fig. 6).

The addition of N, P or NP (both inorganic nitrogen and phosphorus) did not change the net growth rate of picophytoplankton $\left(\mathrm{KW}: \mathrm{H}_{(3, \mathrm{~N}=48)}=0.79, \mathrm{p}>0.05\right)$ while net growth rate 
of the heterotrophic picoplankton increased when adding a NP combination $\left(\mathrm{KW}: \mathrm{H}_{(3, \mathrm{~N}=48)}=\right.$ 20.61, $\mathrm{p}<0.001$ and multiple comparison test: $\mathrm{p}<0.05$; Fig. 5). This pattern suggested a colimitation of nitrogen and phosphorus for the development of heterotrophic picoplankton in the 3 current zones.

The addition of N, P or NP did not change grazing rate on picophytoplankton but increased grazing rate on heterotrophic picoplankton in the presence of the NP combination in the STCC, and inversely decreased grazing rate of heterotrophic picoplankton in the presence of the NP combination in the SECC (Fig. 6).

To summarize, heterotrophic picoplankton was dominant in terms of biomass (Fig. 4), had a better growth (Fig. 5) and was grazed in the 3 current zones (Fig. 6). In contrast, picophytoplankton biomass was low (Fig. 5), grew only in the STCC (Fig. 5), was weakly grazed in the SEC and STCC and was not detectable in the SECC experimental treatments (Fig. 6). Therefore, fluxes inside the food web were mainly based on the heterotrophic pathway. However, the heterotrophic picoplankton exhibited a co-limitation of $\mathrm{N}$ and $\mathrm{P}$ for its development in the 3 current zones.

\subsection{Isotope analyses of POM, meso-macro-zooplankton, micronekton and leptocephali}

\subsubsection{POM isotopic signatures}

Isotopic signatures of POM were highly variable according to currents and depths (Fig. 7). Mean values varied from -26.2 to $-23.16 \%$ in $\delta^{13} \mathrm{C}(-25.1 \pm 1.24 \%$ overall $)$ and from 1.04 to 9.93\% in $\delta^{15} \mathrm{~N}\left(5.57 \pm 2.74 \%\right.$ ) (Fig. 7). A significant effect of depth was observed for $\delta^{13} \mathrm{C}$ (two-way ANOVA, $\mathrm{F}_{2,36}=59.79, \mathrm{p}<0.001$ for depth, $\mathrm{F}_{2,36}=1.88, \mathrm{p}>0.05$ for current zones, $\mathrm{F}_{4,36}=2.21, \mathrm{p}>0.05$ for interaction), and more depleted $\delta^{13} \mathrm{C}$ values were found for the deep and maximum of fluorescence POM compared to at the surface (Tukey: $p<0.001$ for both) (Fig. 7). $\delta^{13} \mathrm{C}$ values were not different between deep and maximum fluorescence (Tukey: $p>$ 0.05). For $\delta^{15} \mathrm{~N}$, significant effects were found both according to depth and current zones (two-way ANOVA, $\mathrm{F}_{2,36}=36.95, \mathrm{p}<0.001$ for depth, $\mathrm{F}_{2,36}=13.09, \mathrm{p}<0.001$ for currents, $\mathrm{F}_{4,36}=0.47, \mathrm{p}>0.1$ for interaction). More $\delta^{15} \mathrm{~N}$ enriched values were found for POM from the SEC and SECC compared to the STCC (Tukey: $\mathrm{p}<0.01$ and $\mathrm{p}<0.001$ for SEC and SECC, respectively), but $\delta^{15} \mathrm{~N}$ values were not different between the SEC and SECC (Tukey: $\mathrm{p}>$ 0.05) (Figs. 7, 8). Finally, POM from deep samples was significantly more enriched in $\delta^{15} \mathrm{~N}$ than POM from the maximum fluorescence and surface layers (Tukey: $p<0.001$ for both), with those layers being not significantly different (Tukey: $p>0.05$ ) (Fig. 7). 
The isotopic landscapes of the region showed a tendency for a north south gradient of $\delta^{15} \mathrm{~N}$ at all depths, with a more patchy distribution at the maximum fluorescence and deeper depths than at surface depths (Fig. 8 left panels). Highest values were observed in the north for the 3 layers and lowest values in the south also for the 3 layers. The deep layer had higher $\delta^{15} \mathrm{~N}$ values (11\%o) while they only reached 6.8\%o at surface and max fluorescence layers as also reflected in Figure 7. Lowest values of $\delta^{15} \mathrm{~N}$ were observed at the surface southern stations with values of $1.2 \%$ areas with the lowest values increasing from the surface to the deep layer (1.2; 2.4 and $6 \%$ at the surface, maximum fluorescence and deep, respectively).

$\delta^{13} \mathrm{C}$ isotopic landscapes ranged over approximately $2 \%$ but they were more patchy regardless of the depth compared to $\delta^{15} \mathrm{~N}$ (Fig. 8, right panels). At the surface, lowest values of POM (-24.8\% to $-24 \%$ ) were observed along a diagonal roughly from south of New Caledonia to south of the Samoan islands between areas of higher $\delta^{13} \mathrm{C}$ (about $-23 \%$ ) to the north and southeast. At maximum fluorescence depths, $\delta^{13} \mathrm{C}$ of POM was patchier and partially inverted compared to northern latitudes, with lowest values of $-26 \%$ to $-25.2 \%$ o observed along a diagonal going from the southwest to the north east of the study area. At the deep layer, higher $\delta^{13} \mathrm{C}$ POM values occurred along southern latitudes and patches of higher $\delta^{13} \mathrm{C}$ values were present within the relatively lower values $(-26.5 \%$ ) in the north.

\subsubsection{Meso-macro-zooplankton isotopic signatures}

A variety of meso-macro-zooplankton taxa with different feeding ecologies were analyzed for isotopic signatures to compare to leptocephali ones (Fig. 9). For euphausids, no difference was found in both $\delta^{13} \mathrm{C}$ and $\delta^{15} \mathrm{~N}$ isotopic ratios between small euphausids $(<10 \mathrm{~mm})$ and bigger euphausids $(>10 \mathrm{~mm})\left(\mathrm{t}\right.$-test: $\mathrm{t}_{24}=0.62, \mathrm{p}>0.05$ and $\mathrm{t}_{24}=0.62, \mathrm{p}>0.05$, respectively for $\delta^{13} \mathrm{C}$ and $\delta^{15} \mathrm{~N}$ ). Thus, they were then pooled into one single group, the euphausids (Fig. 9).

Within each of the 3 current zones most taxa of meso- and macro- zooplankton $\delta^{15} \mathrm{~N}$ isotopic ratio values were similar among the taxa due to high variability (ANOVAs: $p>0.05$ ) despite the fact that large predatory species (Myctophidae, Sagittoidea, Polychaeta and Cephalopoda) tended to have higher averages (notably SEC and STCC) relative to other species. The crustacean taxa (copepods and euphausiidae) had relatively higher values in the SECC zone (Fig. 9). Most individual taxa showed decreasing $\delta^{15} \mathrm{~N}$ values from the north (SECC) to the south (STCC) similar to the pattern observed for POM. However, a few taxa such as chaetognaths and cephalopods had similar values in the SECC and SEC zones and did 
not follow that decreasing trend. This was similar to the little difference observed in $\delta^{15} \mathrm{~N}$ values between POM in the maximum fluorescence layer for the SECC and SEC zones. There were also few consistent differences in the $\delta^{13} \mathrm{C}$ values of each taxa between the SECC and SEC zones, but most taxa had lower values in the STCC zone. The cyanobacteria, Trichodesmium sp. was only collected at stations 55 and 56 in the STCC zone (likely due to a bloom making them visible) and had high $\delta^{13} \mathrm{C}$ isotopic values (-14.59 $\pm 3.43 \%$ ) and very low $\delta^{15} \mathrm{~N}$ ratios $(0.54 \pm 0.39 \%)$ (Fig. 9).

Only the taxa present in sufficient numbers (i.e copepods and euphausids) in the three zones were used to compare the isotopic ratios according to the currents. For euphausids, differences were found in both $\delta^{13} \mathrm{C}$ and $\delta^{15} \mathrm{~N}$ isotopic values among currents (ANOVA: $\mathrm{F}_{2,23}$ $=10.29, \mathrm{p}<0.001$ and ANOVA: $\mathrm{F}_{2,23}=8.30, \mathrm{p}<0.005$, respectively) (Fig. 9). Individuals captured in the STCC had lower $\delta^{13} \mathrm{C}$ (Tukey: $\mathrm{p}<0.01$ ) compared to the two other zones and euphausids captured in the SECC had higher $\delta^{15} \mathrm{~N}$ isotopic values (Tukey: $\mathrm{p}<0.05$ ) relative to the SEC and STCC zones. For copepods, differences in their $\delta^{13} \mathrm{C}$ and $\delta^{15} \mathrm{~N}$ ratios among zones were found $\left(\mathrm{KW}: \mathrm{H}_{(2, \mathrm{~N}=48)}=7.80, \mathrm{p}<0.05\right.$ and ANOVA: $\mathrm{F}_{2,45}=36.84, \mathrm{p}<0.001$, respectively). Individuals in the STCC had lower $\delta^{13} \mathrm{C}$ than those of the SEC (multiple comparison test: $\mathrm{p}<0.05)$. Copepods $\delta^{13} \mathrm{C}$ values in the SECC zone were at an intermediate level between the two other zones. $\delta^{15} \mathrm{~N}$ ratios of copepods in the three zones were significantly different (Tukey: $\mathrm{p}<0.005$ ) with the STCC showing the lowest $\delta^{15} \mathrm{~N}$ values, the SEC intermediate, and the SECC the highest ones.

\subsubsection{Isotope data analysis of mesopelagic fishes from micronekton}

A range of sizes of small fish were analyzed, with undetermined larvae being the smallest (around $10 \mathrm{~mm}$ ), tuna larvae being medium-sized (around $20 \mathrm{~mm}$ ) and Myctophidae being largest (around $40 \mathrm{~mm})$. No difference was found among the $\delta^{13} \mathrm{C}$ values $\left(\mathrm{KW}: \mathrm{H}_{(2, \mathrm{~N}=31)}=\right.$ $1.03, \mathrm{p}>0.05)$ of these fishes because they all had relatively similar values in each of the current zones, except that fish larvae and Myctophidae had relatively high values in the STCC zone in the south (Fig. 11). Significant differences of $\delta^{15} \mathrm{~N}$ signatures were noticed among the three groups of fish (ANOVA: $\mathrm{F}_{2,28}=5.48, \mathrm{p}<0.01$ ) with the Myctophidae being characterized by significantly higher values of $\delta^{15} \mathrm{~N}$ compared to fish larvae (Tukey, $\mathrm{p}<$ 0.05). The $\delta^{15} \mathrm{~N}$ isotopic ratios of fish larvae and Myctophidae both decreased from north to south, and the tuna larvae in the STCC were also low.

For the Myctophidae, $\delta^{13} \mathrm{C}$ ratios were different among the three zones $\left(\mathrm{KW}: \mathrm{H}_{(2, \mathrm{~N}=12)}=\right.$ $6.58, \mathrm{p}<0.05)$, but the multiple comparison test could not identify which area(s) were 
different from other(s) $(\mathrm{p}>0.05)$. Their $\delta^{15} \mathrm{~N}$ signatures were not different among the three zones (ANOVA: $\left.F_{2,9}=4.11, \mathrm{p}>0.05\right)$ even though there was a decreasing trend to the south. For the fish larvae, no difference was found for their $\delta^{13} \mathrm{C}$ values (ANOVA: $F_{2,13}=1.73, p>$ 0.05 ), but significant differences were found for their $\delta^{15} \mathrm{~N}$ signatures (ANOVA: $\mathrm{F}_{2,13}=7.52$, $\mathrm{p}<0.01)$. Fish larvae in the STCC had the lowest $\delta^{15} \mathrm{~N}$ ratios $(4.92 \pm 1.79 \%)$, which were significantly different from those of the SECC (Tukey: $p<0.05$ ) that had the highest values $(10.64 \pm 2.98 \%$ o $)$. Individuals captured in the SEC were at medium levels $(7.50 \pm 2.02 \%$ o between the two others. Tuna larvae were only collected in the STCC (Supplementary Table), so no comparisons between currents was possible.

\subsubsection{Isotopic composition of leptocephali}

Similar to the plankton and other nekton taxa, the leptocephali showed significant variability of $\delta^{13} \mathrm{C}$ and $\delta^{15} \mathrm{~N}$ signatures $\left(\mathrm{KW}: \mathrm{H}_{(2, \mathrm{~N}=91)}=14.55, \mathrm{p}<0.001 ; \mathrm{KW}: \mathrm{H}_{(2, \mathrm{~N}=91)}=\right.$ $39.92, \mathrm{p}<0.001$; respectively) among the 3 currents and the taxa themselves $\left(\mathrm{KW}: \mathrm{H}_{(5, \mathrm{~N}=91)}\right.$ $=36.49, \mathrm{p}<0.001 ; \mathrm{KW}: \mathrm{H}_{(5, \mathrm{~N}=91)}=34.80, \mathrm{p}<0.001$; respectively; Fig. 10). As was observed in the western Indian Ocean (Feunteun et al., 2015), the leptocephali could be separated into two groups of taxa based on their isotopic signatures. On average, Group 1 leptocephali (Congridae, Muraenidae, Serrivomeridae) (Fig. 10, blue colors) had lower $\delta^{13} \mathrm{C}$ and higher $\delta^{15} \mathrm{~N}$ values $\left(\mathrm{MW}: \mathrm{U}_{(1, \mathrm{~N}=91)}=459, \mathrm{Z}=4.03, \mathrm{p}<0.001 ; \mathrm{MW}: \mathrm{U}_{(1, \mathrm{~N}=91)}=433, \mathrm{Z}=4.24, \mathrm{p}<\right.$ 0.001; respectively) compared to the Group 2 leptocephali (Ariosoma, Avocettina, Nemichthys) (Fig. 10, red colors), which are species that grow to larger sizes than those of Group 1. Although there was some overlap in the signatures of individual larvae of each group and there were different sample sizes among taxa, these results were verified for both $\delta^{13} \mathrm{C}$ and $\delta^{15} \mathrm{~N}$ isotopic ratios within each current zone (MW-tests, $\mathrm{p}<0.01$ for all tests). Serrivomerid leptocephali had the highest $\delta^{15} \mathrm{~N}$ signatures in both the SECC and SEC where they were present. In the SEC with the most larvae, the $\delta^{15} \mathrm{~N}$ values of Groups $1(8.60 \pm$ $2.49 \%$ o $)$ and $2(4.97 \pm 1.05 \%$ o $)$ were significantly different and $\delta^{13} \mathrm{C}$ values between Group 1 and 2 (MW-tests, $\mathrm{p}<0.01$ for all tests). The individual taxa within each group also showed both decreased $\delta^{15} \mathrm{~N}$ and $\delta^{13} \mathrm{C}$ mean values from north to south in the 3 current zones (Supplementary Table).

Interestingly, the signatures of most of the leptocephali in each of the 3 zones had a negative relationship between $\delta^{13} \mathrm{C}$ and $\delta^{15} \mathrm{~N}$ (shaded ovals in Fig. 10) when outliers from a few stations were excluded. In the SECC an Avocettina had a very high $\delta^{15} \mathrm{~N}$ (from the northeastern-most station 64) and other individuals had much lower values that were from a 
northeastern station. In the SEC, the leptocephali had a similar range of $\delta^{13} \mathrm{C}$ values, but most had lower $\delta^{15} \mathrm{~N}$ signatures than those of the SECC. The exception were the larvae from station 65 that was located just southwest of the island of Samoa, which had a higher range of $\delta^{15} \mathrm{~N}$. Other outliers were Muraenidae larvae from the southeast area of the SEC. In the STCC, the Congridae larvae (station 34 and 37 in the southwest) showed the highest $\delta^{15} \mathrm{~N}$ values, but the Muraenidae and nemichthyid leptocephali overlapped in their signatures with the Group 2 larvae. A $114 \mathrm{~mm}$ Bathycongrus leptocephalus had lower $\delta^{15} \mathrm{~N}$ and $\mathrm{C}$ values than other congrids.

\subsubsection{Comparison of leptocephali isotopic ratios to other groups}

The plots of all the mean values of the different taxa of leptocephali, crustaceans, micronekton, POM and Trichodesmium in each of the 3 current zones showed some interesting consistencies but also some variability among the zones (Fig. 11). The cyanobacteria, Trichodesmium sp., were only collected in the STCC zone (although likely present), had the highest $\delta^{13} \mathrm{C}$ ratio and the lowest $\delta^{15} \mathrm{~N}$ ratio. The $\delta^{13} \mathrm{C}$ gap between POM from the 3 depths and the taxa of marine organisms was about the same within the northern current zones but was reduced in the STCC. The overlap between the $\delta^{15} \mathrm{~N}$ values of POM and organisms increased from north to south. In the SECC many taxa had higher $\delta^{15} \mathrm{~N}$ than the deep POM, but in the STCC almost no taxa had higher values.

The relationship between the taxa of leptocephali, crustaceans and micronekton also showed some variability among the current zones (Fig. 11). The micronekton usually had higher $\delta^{13} \mathrm{C}$ values than leptocephali, and their $\delta^{15} \mathrm{~N}$ values were mostly higher than leptocephali in the SECC and SEC and showed more overlap in the STCC. The crustacean taxa showed various types of overlapping values with lower $\delta^{13} \mathrm{C}$ of some taxa compared to leptocephali in the SECC or mostly overlapping values in the SEC. In the SEC, Avocettina and Nemichthys had the lowest $\delta^{15} \mathrm{~N}$ values, which were close to the values of POM at the surface and maximum fluorescence (Fig. 11). In the STCC, the $\delta^{15} \mathrm{~N}$ values of Ariosoma and Avocettina were almost the same low value, which was slightly higher than the POM at the surface and slightly lower than the POM at the maximum fluorescence (Fig. 11).

\section{Discussion}

\subsection{Pelagic environment in the WSP region}

The hydrographic structure observed in the WSP in February 2013 included the low salinity Fresh Pool in the STCC zone and part of the northern SEC, and the warmer water 
mixed layer of surface water became gradually shallower and mostly disappeared in the southern STCC zone, which are typical features of the region (Miller et al., 2006b; Schabetsberger et al., 2016). The highest salinities of the STUW centered on the 100-200 m layer were only present in the STCC and SEC zones. The maximum fluorescence layer was centered at about $100 \mathrm{~m}$ and deeper in the east. Therefore, the 3 latitudinal current zones we used for analyses had different hydrographic characteristics. Our zonal separations were only approximations and there is likely some overlap in water masses that results from eddy exchange and countercurrent jets as can be inferred from the complexity of the currents in the region (Ganachaud et al., 2014), which might account for some of the variability that was observed. We also compared some microbial biomasses, the functioning of the microbial loop, and POM signatures in the warm surface layer $(5 \mathrm{~m})$ above the STUW, the maximum fluorescence layer near the top of the thermocline within the STUW and the deeper layer in the middle of the thermocline and below the STUW.

The concentration of nutrients in our study showed the typical characteristics of oligotrophic ecosystems, as was observed in another recent study in the WSP (Bonnet et al., 2018). But nitrogen and phosphate concentrations were slightly higher in New Caledonian waters during an El Niño episode (Tenório et al., 2018) or in the Southwestern Pacific Ocean (Campbell et al., 2005) compared to our study. However, there was some variability in nutrient levels among our stations in 2013 such as the unusually high silicate value (St. 39) in an area where there could be eastward flowing water of the Coral Sea Countercurrent (Ganachaud et al., 2014) passing through the Vanuatu Islands. Upwelling of high silicates (Leblanc et al., 2018) and nitrates (Blanchot and Rodier, 1996) has been observed in that general area. DiTullio et al. (2003) also found some variability in nutrient levels along $170^{\circ} \mathrm{W}$ in the South Pacific Ocean.

\subsection{Characteristics of the microbial loop structure}

The three depths sampled in the upper $260 \mathrm{~m}$ of the water column were dominated by heterotrophic organisms that were primarily heterotrophic picoplankton (e.g. bacteria). In the North Pacific Ocean $\left(137-155^{\circ} \mathrm{E}\right)$, Yamaguchi et al. (2004) showed the importance of bacterial biomass, which was similar to our study. Secondly, heterotrophic nanoflagellates also were relatively abundant especially in the maximum fluorescence depths $(80-145 \mathrm{~m}$ depending of stations).

Within the primary producers, small phytoplanktonic cells (pico-nano-phytoplankton) were more abundant compared to the very low biomass of microphytoplankton. Due to the 
low nutrient concentrations in this area, microphytoplankton organisms were generally scarce along $170^{\circ} \mathrm{W}$ (our easternmost transect) in the offshore parts of the gyre compared to higher latitudes during the summer season (DiTullio et al., 2003). In contrast, picophytoplankton dominated across all 3 of our current zones as was observed in the studies of Blanchot and Rodier (1996), DiTullio et al. (2003), Campbell et al. (2005) and Grob et al. (2007). Their abundance in previous studies was highest between the surface $(5 \mathrm{~m})$ and around $80-100 \mathrm{~m}$ (corresponding to a maximum fluorescence depths) in our study.

The presence of Trichodesmium (i.e. a diazotroph cyanobacteria, which fixes atmospheric $\mathrm{N}_{2}$ ) was detected in the STCC zone in February 2013 in our study, as was observed in previous studies (e.g. Bonnet et al., 2018). However, Campbell et al. (2005) also found Trichodesmium in the SEC in March-April. The occurrence of Trichodesmium fluctuates near New Caledonia (Tenório et al., 2018), maybe due to a limitation by nitrate availability (Moutin et al., 2005). In oligotrophic ecosystems that are "nitrogen-depleted", diazotroph organisms can overcome the N-limitation and are thus important contributors to the primary productivity (e.g. Bonnet et al., 2018).

The microbial loop at the maximum fluorescence layers was examined by onboard experiments. The net growth rate and grazing rate of picophytoplankton and heterotrophic picoplankton were determined using water from the maximum fluorescence depth. Consequently, these results cannot be extrapolated to the entire photic zone. The main results showed the relatively high abundance, growth rate of heterotrophic microorganisms and grazing rate on heterotrophic microorganisms. As far as we know, this is the first time that these kinds of measurements have been performed on components of the microbe food web in this region. Carlotti et al. (2018) studied mesozooplankton structure and functioning in the south western Pacific, but not the associated microbe food web, so no comparison is possible. Despite the low nutrient concentration observed in situ, no growth of phytoplankton community was induced when adding nitrogen and phosphorus. Heterotrophic picoplankton grew well and was well grazed, as demonstrated in an oligotrophic aquatic system (Samuelsson and Andersson, 2003). Therefore, fluxes inside the microbe food web were mainly based on the heterotrophic pathway. However, in the 3 current zones, the development of heterotrophic picoplankton was co-limited by nitrogen and phosphorus. The picophytoplankton community did not respond to the addition of nitrogen and phosphorus possibly because heterotrophic picoplankton are much more competitive than picophytoplankton (Thingstad and Rassoulzadegan, 1995). 
Even if all the grazing experiments did not work, the tendency was clear that the water column was dominated by heterotrophic organisms, with relatively high growth rates of heterotrophic microorganisms and also high grazing rates on heterotrophic microorganisms. In addition, primary producers were N-P co-limited. All of our observations appeared to be consistent with typical characteristics of oligotrophic areas.

\subsection{Variability of POM signatures with latitude and depth}

One of the most interesting finding of our study was that several patterns were observed in the isotopic signatures of the POM (including marine snow aggregates), which was analyzed from the water samples filtered with $0.7 \mu \mathrm{m}$ mesh at different depths and latitudes. A patchy isotopic landscape of $\delta^{15} \mathrm{~N}$ and $\delta^{13} \mathrm{C}$ that was observed that could be a result of the eddies that occur within the southwest Pacific Ocean (e.g. DiTullio et al., 2003). The POM of the SECC and SEC zones was enriched in $\delta^{15} \mathrm{~N}$ compared to the STCC zone in the south. There was some east-west variability in the basic latitudinal trend among the zones, but the $\delta^{15} \mathrm{~N}$ values were generally higher in the north and lower in the south. Similar latitudinal changes in isotopic signatures have been observed in other regions and in highly mobile marine animals such as tunas (Estrada et al., 2005; Ménard et al., 2007; Lorrain et al., 2015). Distinct geographic differences in the $\delta^{15} \mathrm{~N}$ signatures of POM were found by Houssard et al. (2017), which are consistent with the decreasing $\delta^{15} \mathrm{~N}$ values of POM and other organisms from north to south in our study. In the STCC, the Trichodesmium present in this area would be a greatly depleted source of $\delta^{15} \mathrm{~N}$, especially for the isotopic signatures of surface POM (our results; Waite et al., 2007 ; Somes et al., 2010; Bonnet et al., 2018). )Nevertheless, Campbell et al. (2005) found Trichodesmium in the SEC in March-April and this may affect the isotopic POM signatures of all the food webs in this area during this season.

In addition, depth patterns were observed with differences in both $\delta^{15} \mathrm{~N}$ and $\delta^{13} \mathrm{C}$ signatures occurring according to the sampling depth of POM. POM composition in the deep layer (200-260 m) that was likely dominated by heterotrophic organisms (pico-nanoplankton) was enriched in nitrogen compared to the surface and maximum fluorescence $(80-145 \mathrm{~m})$ depths, and higher $\delta^{13} \mathrm{C}$ values were observed in the surface POM. Miyazaki et al. (2011) also found the highest $\delta^{15} \mathrm{~N}$ signatures of POM in the deeper layers, and their signatures at the surface $(5 \mathrm{~m})$ overlapped with intermediate depths. Hannides et al. (2013) found that POM also had the lowest $\delta^{15} \mathrm{~N}$ near the surface $(<2 \%$ above $50 \mathrm{~m})$ and the values remained much higher ( $>8 \%$ ) below about $120 \mathrm{~m}$ in the North Pacific subtropical gyre. The same basic trend was also seen in the southeastern North Pacific for POM $(0.7-53 \mu \mathrm{m})$ where there were high 
$\mathrm{N}$ values $(>8 \%$ ) below about $100 \mathrm{~m}$ (Williams et al., 2014). In contrast, POM at the surface $\left(5 \mathrm{~m}, 5 \%\right.$ ) also had slightly higher $\delta^{15} \mathrm{~N}$ values than at $100 \mathrm{~m}(4 \%)$ in the western Indian Ocean in January-February 2010 (Feunteun et al., 2015). These different $\delta^{15} \mathrm{~N}$ isotopic signatures were likely reflecting the different relative biomasses of the various sizes of heterotrophic and autotrophic microorganisms detected at the different depths.

\subsection{Representation of the food web in the western South Pacific Ocean}

Our 3 approximated current zones were spread across a region with many island groups and various latitudinal gradients in many parameters such as temperature, salinity, and productivity (e.g. DiTullio et al., 2003), so they only roughly characterized the diversity of biological oceanographic conditions in those regions of the WSP. As a result, signatures likely differed among some stations within each designated zone because of factors such as eddies and current jets. Despite that likelihood, some overall patterns in the isotopic signatures of organisms were observed with depth and latitude that are reflecting changes in some aspects of the trophic structure of the food webs there.

Firstly, Minagawa and Wada (1984) found that the trophic enrichment factor (TEF $_{\text {prey- }}$ predator) for nitrogen isotopic values between two trophic level is generally about $3.4 \pm 1.1 \%$ (see also Post, 2002), and many authors consider the carbon enrichment to be $\mathrm{TEF}_{\text {prey-predator }}=$ 1\%o (DeNiro and Epstein, 1978; Rau and Anderson, 1981; Fry and Arnold 1982; Peterson and Fry, 1987). If these TEF factors are applied to our results, it suggests there were two kinds of sources of the food web, possibly in part because of Trichodesmium was only observed in STCC zone. Our isotopic analyses showed some expectable patterns such as the mean values of the micronekton signatures being partially separated from the crustaceans and leptocephali, and they were most distinctly separated with both higher $\delta^{15} \mathrm{~N}$ and $\delta^{13} \mathrm{C}$ signatures in the SEC zone. Cephalopods (Hanlon, 1987), chaetognaths (Terazaki and Marumo, 1982), annelids and myctophids are carnivores that feed on macro-mesozooplankton and small fish larvae. Small fishes are often known to feed on meso- microzooplankton (Last, 1978; Mehner et al., 1996; Post and Kitchell, 1997). Both leptocephali and crustaceans however, showed various patterns of signatures compared to each other in the 3 current zones. Some copepods can be considered as carnivorous like Pleuromamma abdominalis, Pleuromamma xiphias (Gueredrat, 1971), Metridia venusta and some species of Calanoidae since they showed relatively high values of $\delta^{15} \mathrm{~N}$. Adult stages of the genus Euphausia are generally carnivorous, but the species found in this study were small and they can consume POM (Schnetzer and 
Steinberg, 2002). Fish larvae can also consume POM (Larson and Shanks, 1996), which might explain their intermediate $\delta^{15} \mathrm{~N}$ values in our study.

A large gap in $\delta^{13} \mathrm{C}$ between POM and grazers was observed in our data with each current zone. A similar gap between POM and some leptocephali and potential grazers was observed in similar isotopic analyses made to the west of the Mascarene Plateau in the Indian Ocean (Feunteun et al., 2015; Lienart et al. 2016). Consequently, if "grazers" do feed on POM, they probably select or assimilate some particular kinds of POM (Feunteun et al., 2015; Lienart et al. 2016), and this is discussed more for leptocephali in the next section. A complementary hypothesis is that the POM grazers would likely be feeding on "marine snow", and not on the free-living component of POM, which was dominated by heterotrophic picoplankton in our study. This may be one explanation for the large gap in $\delta^{13} \mathrm{C}$ between POM and grazers in our data within each current zone. In the south (STCC), most taxa showed lower $\delta^{15} \mathrm{~N}$ values similar to POM as influenced by the presence of Trichodesmium. Therefore, our results indicate there are food webs based on a mixture between POM and Trichodesmium, that form two kinds of sources of food webs in the southern WSP. Carlotti et al. (2018) estimated that mesozooplankton remove daily $1.5 \%$ to $22 \%$ of $\mathrm{N}_{2}$ stocks fixed by phytoplankton in the western tropical South Pacific along $20^{\circ} \mathrm{S}$, suggesting considerable variability is present, as we observed in our study.

\subsection{Linkage of leptocephali and POM isotopic signatures within the WSP food webs}

The analyses of the stable isotopic signatures of the 6 major taxa of leptocephali in relation POM and other food web components the 3 current zones showed some interesting trends not observed in previous studies on fewer taxa or in more limited geographic areas. Within each current zone of the WSP, the signatures showed similar patterns for the two groups of taxa of leptocephali (as designated by Feunteun et al., 2015), with Group 1 (high $\delta^{15} \mathrm{~N}$, low $\delta^{13} \mathrm{C}$; Congridae, Muraenidae, Serrivomeridae) and Group 2 (low $\delta^{15} \mathrm{~N}, \delta^{13} \mathrm{C}$ high; species that grow to large larval sizes: Avocettina, Nemichthys and Ariosoma) having similar relationships within each current zone. This relationship between the 2 groups is essentially the same as what was observed in leptocephali collected in a tight grid of stations located on the downstream side of the Mascarene Plateau where the flow of the Indian Ocean SEC passed through the shallow banks where some eels were spawning and other eels were spawning offshore (Feunteun et al., 2015; Miller et al., 2015, 2019b). In addition, an Ariosoma species (Group 2) also showed clearly lower $\delta^{15} \mathrm{~N}$ values compared to Anguilla (Group 1) in the North Equatorial Current of the western Pacific (Miyazaki et al., 2011). The same clear relationship 
between many Group 1 taxa of leptocephali and Ariosoma and Nemichthys (Group 2) was also seen in a larger study of the isotopic signatures of leptocephali from the NEC in November 2013 (Onda, 2017; Onda et al., 2017), and it was observed in the Gulf of Mexico, along with a few outlier values (Quattrini et al., 2019). These differences do not appear to be related to the actual size of the larvae being isotopically analyzed in our study (not shown) or in a previous study that examined isotopic signatures in relation to larval size (Feunteun et al., 2015). This suggests these groups may constitute a typical pattern of isotopic signatures among leptocephali from oligotrophic ocean gyres, despite the fact that the long larval duration of leptocephali allows for the mixing of larvae from different geographic origins.

Our leptocephali data had some outliers from the main range of signatures in each zone, which were very large larvae (Avocettina, Nemichthys, Bathycongrus) that would have been drifting for many months. Considering the geographic variation in $\delta^{15} \mathrm{~N}$ values shown in our study and by Houssard et al. (2017) in the WSP, these large larvae may have come from areas with different signatures than the zones they were collected in. Another interesting finding was that all the leptocephali and other taxa at St. 65 within the SEC zone had higher $\delta^{15} \mathrm{~N}$ values more like the signatures in the SECC. It is unclear if the water in that area had been transported there from the north, but the POM in the upper sampling layers had higher signatures than at the stations to the east. The high $\delta^{15} \mathrm{~N}$ signatures at that station added some variability into our comparisons of the various taxa among the 3 zones, but the general position of leptocephali in the plots of average $\delta^{15} \mathrm{~N}$ and $\delta^{13} \mathrm{C}$ signatures of all taxa and POM were similar within each current zone.

Our distribution of stations was not perfect for examining the latitudinal variation in isotopic signatures due to several stations being very close to the zone boundaries, the presence of east-west variations in the POM signatures, and some taxa such as Serrivomeridae were more abundant in the north than the south (see Liénart et al., 2016). However, there was an overall trend of $\delta^{15} \mathrm{~N}$ signatures decreasing from north to south in all the taxa examined, and the leptocephali generally followed this trend. The signatures of leptocephali were therefore linked with the overall food web.

Interestingly, understanding how leptocephali are positioned within the food web needs to be approached differently than for most other marine animals whose feeding niches are more well defined, because of their unique feeding ecology. Direct observations of the gut contents of leptocephali (Otake et al., 1993; Mochioka and Iwamizu, 1996; Miller et al., 2011, 2019; Tomoda et al., 2018) and the diversity of taxa detected using DNA sequencing of anguillid leptocephali gut contents (Riemann et al., 2010; Ayala et al., 2018) have shown that 
leptocephali consume marine snow materials. The guts of leptocephali are usually partially or mostly empty, probably due to their soft bodies and the capture process, but when food is present it appears as amorphous materials or includes detrital-like marine snow or roundish objects (Mochioka and Iwamizu, 1996; Miller et al., 2011; Tomoda et al., 2018). A study of leptocephali gut contents in the Sargasso Sea suggests that some of these roundish objects are thraustochytrid protists (Miller et al., 2019a). These protists and other groups of the Labyrinthulomycetes cannot be detected genetically unless appropriate PCR primers are used (e.g. Li et al., 2013), so they were not detected in the gut contents of leptocephali in the Sargasso Sea (Riemann et al., 2010; Ayala et al., 2018). They have been found within marine snow aggregates (Li et al., 2013; Bochdansky et al., 2017), so they may be a previously unrecognized component of some types of marine snow that is consumed by leptocephali.

Feeding on marine snow, therefore makes the diet of leptocephali difficult to define clearly, because marine snow is a broad category of detrital materials that originates from a wide range of sources and is colonized by many types of small organisms (Alldredge and Silver, 1988; Shanks and Walters, 1997; Kiørboe, 2000; Bochdansky et al., 2017) including bacteria (Pomeroy and Deibel, 1980) and can contain a wide diversity of DNA sequences (Ayala et al., 2018). In addition, some abundant marine organisms, such as protists will require new techniques to be detected. Consequently, the content of marine snow particles will directly depend on the activity within the food web at each location and on what material is being released at each depth. Further complicating the question of what each type of materials leptocephali feed on is that they can ingest distinguishable objects that contribute to marine snow such as appendicularian houses (Mochioka and Iwamizu, 1996; Miller et al., 2011), which are discarded frequently after their filters clog up with materials present in the water that is being filtered to obtain food. Marine snow also contains carbohydrates that originate from transparent exoparticles (TEP) that are released from phytoplankton or bacteria (Alldredge et al., 1993; Passow, 2002; Engel, 2004). In addition, the widely abundant small calycophoran siphonophores are seemingly contributing some kind of material to what is consumed by leptocephali, at least in the Sargasso Sea of the North Atlantic (Ayala et al., 2018). This means that different sizes or types of marine snow can include materials ranging from being directly from primary producer phytoplankton (TEP), or being from secondary consumers (siphonophores), or from a variety of sources aggregated into individual marine snow particles, which can be diverse in their content in oligotrophic areas (Ayala et al., 2018).

Considering these factors, perhaps it is not surprising that different isotopic signatures were observed among leptocephali. Despite the long larval life of leptocephali and the 
likelihood of some larvae from different geographic areas mixing together, the two isotopic groups of leptocephali appears to be a consistent pattern observed in each study that has included those taxa (Miyazaki et al., 2011; Feunteun et al., 2015; Onda, 2017; Quattrini et al., 2019). Because Group 2 consists of the species that grow to much larger sizes (Avocettina, Nemichthys and Ariosoma) than all other anguilliform leptocephali, it cannot be assumed there are not some kind of physiological differences in isotopic fractionation between the two groups. Isotopic fractionation is a poorly understood process that might change according to species, tissues, or trophic levels. Organisms that have different assimilation rates or also different tissue turnover rates depending on the type or organisms and physiological status/growth can differ in their trophic level fractionation (Ambrose and Norr, 1993), and different degrees of fractionation of nitrogen isotopes have been detected along trophic linkages (Gannes et al., 1998; McCutchan et al., 2003). Furthermore, individuals belonging to the same family with the same diet, have shown differences reaching more than $2 \%$ for $\delta^{13} \mathrm{C}$ isotopic signatures (DeNiro and Epstein, 1978; Voigt et al., 2003). It therefore seems possible that some of the differences between the two groups is resulting from physiological differences related to growing to larger sizes.

If this is not the case, then an obvious alternative explanation clearly suggested by the present study is that the two groups may be feeding at different depths where the marine snow has different isotopic signatures. Serrivomeridae followed by Congridae generally had the highest $\delta^{15} \mathrm{~N}$ levels, followed by Muraenidae that had more variable levels, so these species may tend to feed at deeper depths than Avocettina, Nemichthys and Ariosoma, which could feed more at shallower depths. This is consistent with the low POM $\delta^{15} \mathrm{~N}$ signatures at the surface or within the fluorescence maximum, but the high $\delta^{13} \mathrm{C}$ signatures of the Group 2 larvae suggests they may feed closer to the surface where our POM had clearly higher $\delta^{13} \mathrm{C}$ values. Leptocephali are known to sometimes vertically migrate (Castonguay and McCleave, 1987) like other planktonic organisms (Hays, 2003; Tarling, 2003), and they are usually found in the upper $100 \mathrm{~m}$ at night (Castonguay and McCleave, 1987; Otake et al., 1998; Miller, 2009, 2015; Onda et al., 2017). Different taxa of leptocephali have also been found at different depth zones within the upper $100 \mathrm{~m}$ at night including at individual stations (Miller, 2009, 2015; Onda et al., 2017). Information on the depths used by leptocephali during the day, when they are likely feeding is more limited however due to possible net avoidance (see Miller et al., 2013a). In the Sargasso Sea, anguillid, muraenid, chlopsid and serrivomerid leptocephali (Group 1), seemed to move from $<100 \mathrm{~m}$ depths during nighttime to depths mostly $<250 \mathrm{~m}$ during the day (Castonguay and McCleave, 1987) where there can be high 
$\delta^{15} \mathrm{~N}$ POM signatures (our study; Miyazaki et al., 2011; Hannides et al., 2013; Williams et al., 2014; Feunteun et al., 2015). In contrast that study found no evidence of Group 2 species vertically migrating to deeper depths during the day, which is consistent with the possibility that they feed at shallower depths compared to Group 1 species.

While the general relationships of higher or lower values of leptocephali and POM from different depths compared to each other show possible correspondences, the gaps between the two do not seem to correspond to traditional fractionation values (DeNiro and Epstein, 1978; Rau and Anderson, 1981; Fry and Arnold, 1982; Peterson and Fry, 1987; Post, 2002). This is typical of the isotopic studies of leptocephali, zooplankton, and POM (Miyazaki et al., 2011; Feunteun et al., 2015; Dupuy et al., 2016; Lienart et al. 2016). Those studies, the present study, and typical studies including POM (e.g. Dupuy et al., 2016) use a $0.7 \mu \mathrm{m}$ filter pore size, but the marine snow particles that leptocephali can feed on are much larger than that (more on the scale of millimeters). This means that the POM that is analyzed includes freeliving plankton taxa, which are not included in the size of marine snow that leptocephali feed on. Waite et al. (2007) showed that POM $>20 \mu \mathrm{m}$ was both about $2 \% \delta^{15} \mathrm{~N}$ and $\delta^{13} \mathrm{C}$ higher

than $\mathrm{POM}<5 \mu \mathrm{m}$, so size of the POM particles consumed by leptocephali is likely an important factor. Therefore, there is no clear expectation that the signatures of leptocephali (feeding on marine snow) and POM (marine snow and many other materials $\geq 0.7 \mu \mathrm{m}$ ) should match precisely according to normal fractionation values, because as pointed out previously, leptocephali are likely selecting some components of the total POM samples (Feunteun et al., 2015; Liénart et al., 2016). In the future, an Underwater Vision Profiler coupled with a "Appinet" or marine snow catcher could be used to gather in situ diversity and abundance information about marine snow particles as was done by Duret et al. (2019) and Lundgreen et al. (2019).

\subsection{Conclusions}

The region of the WSP that we studied during February 2013 varied hydrographically and biologically with latitude, and different isotopic compositions and microbial compositions were found at the three depths we examined. Heterotrophic picoplankton was dominant at all three depths and phytoplankton (mainly small size) and heterotrophic nanoflagellates were mostly present within the maximum fluorescence layer. The pico-nano-microplankton was both $\mathrm{N}$ and $\mathrm{P}$ limited within the maximum fluorescence layer and the 3 currents zones were based on a heterotrophic planktonic functioning. All of our observations appeared to be 
consistent with typical characteristics of oligotrophic subtropical gyres; however, this particular region is interesting because of the alternating east and west current zones as well as other smaller current jets, which likely result in mixing of water masses. Generally, consistent patterns of the isotopic signatures of POM, leptocephali, zooplankton and micronekton were observed, with the baseline $\delta^{15} \mathrm{~N}$ signatures of all components generally decreasing from north to south, with some east-west variation also seen in POM values. Furthermore, the presence of Trichodesmium in the STCC surface zone would influence the isotopic signatures of POM and consequently leptocephali. The signatures of leptocephali were therefore linked to the overall food web because all evidence indicates that they feed on the larger size range of the marine snow. The apparent two groups of leptocephali with different isotopic signatures may be explained by feeding behavior at different depths or on different types of marine snow. Further studies need to examine marine snow particles at different depths directly to determine what types of particles each type and size of leptocephali may feed on to begin to fully understand the feeding ecology of leptocephali in the WSP and each region of the world. In addition, more research is needed using stable isotope analysis of leptocephali and other food web components, such as small mesozooplankton $(<0.5 \mathrm{~mm})$ that were not sampled in this study, across a wider horizontal scale to gain a better understanding of the feeding ecology of this interesting type of fish larvae.

\section{Acknowledgements}

We thank the captain and crew of the R/V Hakuho Maru for their expert assistance in collecting the specimens and hydrographic data, and we appreciate the help from all the other scientists and technicians for sorting the plankton samples and deployment of the sampling gear. We also thank Bastien Bourrillon, PhD student of the MNHN, for making the POM contour map.

\section{Author contributions}

C.D., A.C., E.F., A.C., and CLi. collected the specimens and data during the sampling survey that was designed and managed by T.O., K.T., J.A., and S.W. The leptocephali were identified on board by M.J.M. and M.K., the specimen data was analyzed by L.G., C.D., E.F., CLi., and Cle., and L.G. and M.J.M. made the figures. C.D., L.G., M.J.M., and E.F. drafted the manuscript and all coauthors approved the manuscript 


\section{References}

Alldredge, A.L. 1972. Abandoned larvacean houses, a unique food source in the pelagic environment. Science 177, 885-887.

Alldredge, A.L. 1976. Discarded appendicularian houses as sources of food, surface habitats, and particulate organic matter in planktonic environments. Limnology and Oceanography 21, 14-23.

Alldredge, A.L., Silver, M.W. 1988. Characteristics, dynamics and significance of marine snow. Progress in Oceanography 20, 41-82.

Alldredge, A.L., Passow, U., Logan, B.E. 1993. The abundance and significance of a class of large, transparent organic particles in the ocean. Deep-Sea Researc I 40, 1131-1140.

Ambrose, S.H., Norr, L. 1993. Experimental evidence for the relationship of the carbon isotope ratios of whole diet and dietary protein to those of bone collagen and carbonate. Prehistoric Human Bone, 1-37.

Aminot, A., Kerouel, R. 1982. Dosage automatique de l'urée dans l'eau de mer: une méthode très sensible à la diacétylmonoxime. Canadian Journal of Fisheries and Aquatic Sciences $39,174-183$.

Ayala, D.J., Munk, P., Lundgreen, R.B.C., Traving, S.J., Jaspers, C., Jørgensen, T.S., Hansen, L.H., Riemann, L. 2018. Gelatinous plankton is important in the diet of European eel (Anguilla anguilla) larvae in the Sargasso Sea. Scientific Reports 8, 6156.

Barboza Tenório, M.M., Dupouy, C., Rodier, M., Neveux, J. 2018. Trichodesmium and other planktonic cyanobacteria in New Caledonian waters (SW tropical Pacific) during an El Niño episode. Aquatic Microbiology and Ecology 81, 219-241.

Blanchot, J., Rodier, M. 1996. Picophytoplankton abundance and biomass in the western Tropical Pacific Ocean during the 1992 El Nino year: Results from flow cytometry, Deep-Sea Research 43, 877-896.

Bochdansky, A.B., Clouse, M.A., Herndl, G.J. 2017. Eukaryotic microbes, principally fungi and labyrinthulomycetes, dominate biomass on bathypelagic marine snow. The ISME Journal 11, 362-373.

Bode, A., Álvarez-Ossorio, M.T. 2004. Taxonomic versus trophic structure of mesozooplankton: a seasonal study of species succession and stable carbon and nitrogen isotopes in a coastal upwelling ecosystem. ICES Journal of Marine Science 61, 563571. 
Bonnet, S., Caffin, M., Berthelot, H., (...), Stenegren, M., Foster, R.A. 2018. In-depth characterization of diazotroph activity across the western tropical South Pacific hotspot of $\mathrm{N}_{2}$ fixation (OUTPACE cruise). Biogeosciences 15, 4215-4232.

Bodin, N., Le Loc'h, F., Hily, C. 2007. Effect of lipid removal on carbon and nitrogen stable isotope ratios in crustacean tissues. Journal of Experimental Marine Biology and Ecology 341, 168-175.

Böhlke, E.B. 1989a (ed) Fishes of the Western North Atlantic. Orders Anguilliformes and Saccopharyngiformes. Part 9, Vol. 1, pp. 1-655. Sears Foundation for Marine Research, New Haven.

Böhlke, E.B.1989b (ed) Fishes of the Western North Atlantic. Leptocephali. Part 9, Vol. 2, pp. 657-1055. Sears Foundation for Marine Research, New Haven.

Bouvy, M., Bettarel, Y., Bouvier, C., Domaizon, I., Jacquet, S., Le Floc'h, E., Montanié, H., Mostajir, B., Sime-Ngando, T., Torréton, J.P., Vidussi, F., Bouvier, T. 2011. Trophic interactions between viruses, bacteria and nanoflagellates under various nutrient conditions and simulated climate change. Environmental Microbiology 13, 1842-185.

Campbell, L., Carpenter, E.J., Montoya,J.P., Kustka,A.B., Capone,D.G., 2005. Picoplankton community structure within and outside a Trichodesmium bloom in the southwestern Pacific Ocean. Life Environ. 55, 185-195.

Carlotti, F., Pagano, M., Guilloux, L., Donoso, K., Valdés, V., Grosso, O., Hunt, B.P.V. 2018 Meso-zooplankton structure and functioning in the western tropical South Pacific along the 20th parallel south during the OUTPACE survey (February-April 2015). Biogeosciences 15, 7273-7297.

Caron, D.A. 1983. Technique for enumeration of heterotrophic and phototrophic nanoplankton, using epifluorescence microscopy, and comparison with other procedures. Applied Environmental Microbiology 46, 491-498.

Castle, P.H.J. 1984. Notacanthiformes and Anguilliformes: Development. pp. 62-93. In: H.G. Moser et al. (ed.) Ontogeny and Systematics of Fishes, Special Publication 1, American Society of Ichthyologists and Herpetologists, Allen Press, Lawrence.

Castonguay, M., McCleave, J.D. 1987. Vertical distributions, diel and ontogenetic vertical migrations and net avoidance of leptocephali of Anguilla and other common species in the Sargasso Sea. Journal of Plankton Research 9, 195-214.

Chen, S., Qiu, B. 2004. Seasonal variability of the South Equatorial Countercurrent. Journal of Geophysical Research 109, C08003. 
Chouvelon, T., Chappuis, A., Bustamante, P., Lefebvre, S., Mornet, F., Guillou, G., Violamer, L., Dupuy, C. 2014. Trophic Ecology of European Sardine Sardina Pilchardus and European Anchovy Engraulis Encrasicolus in the Bay of Biscay (north-East Atlantic) Inferred from $\delta{ }^{13} \mathrm{C}$ and $\delta{ }^{15} \mathrm{~N}$ Values of Fish and Identified Mesozooplanktonic Organisms. Journal of Sea Research 85, 277-91.

Chow, S., Kurogi, H., Katayama, S., Ambe, D., Okazaki, M., Watanabe, T., Ichikawa, T., Kodama, M., Aoyama, J., Shinoda, A., Watanabe, S., Tsukamoto, K., Miyazaki, S., Kimura, S., Yamada, Y., Nomura, K., Tanaka, H., Kazeto, Y., Hata, K., Handa, T., Tawa, A., Mochioka, N. 2010. Japanese eel Anguilla japonica do not assimilate nutrition during the oceanic spawning migration: evidence from stable isotope analysis. Marine Ecology Progress Series 402, 233-238.

Craig, H. 1957. Isotopic standards for carbon and oxygen and correction factors for massspectrometric analysis of carbon dioxide. Geochimica et cosmochimica acta 12, 133149.

Deibel, D., Parrish, C.C., Grønkjaer, P., Munk, P., Nielsen, T.G. 2012. Lipid class and fatty acid content of the leptocephalus larva of tropical eels. Lipids 47, 623-634.

DiTullio, G.R., Geesey, M.E., Jones, D.R., Daly, K.L., Campbell, L., Smith, W.O. 2003. Phytoplankton assemblage structure and primary productivity along $170^{\circ} \mathrm{W}$ in the South Pacific Ocean. Marine Ecology Progress Series 255, 55-80.

Duret, M.T., Lampitt, R.S., Lam, P. 2019 Prokaryotic niche partitioning between suspended and sinking marine particles. Environmental Microbiology Reports 11, 386-400.

Dupuy, C., Pagano, M., Got, P., Domaizon, I., Chappuis, A., Marchessaux, G., Bouvy, M. 2016. Trophic relationships between metazooplankton communities and their plankton food sources in the Iles Eparses (Western Indian Ocean). Marine Environmental Research 116, 18-31.

Ehleringer, J.R., Rundel, P.W. 1989. Stable isotopes: history, units, and instrumentation. In Stable isotopes in ecological research, pp 1-15.

Engel, A., 2004. Distribution of transparent exopolymer particles (TEP) in the northeast Atlantic Ocean and their potential significance for aggregation processes. Deep-Sea Research I 51, 83-92.

Estrada, J.A., Lutcavage, M., Thorrold, S.R. 2005. Diet and trophic position of Atlantic bluefin tuna (Thunnus thynnus) inferred from stable carbon and nitrogen isotope analysis. Marine Biology 147, 37-45. 
Feunteun, E., Miller, M.J., Carpentier, A., Aoyama, J., Dupuy, C., Kuroki, M., Pagano, M., Réveillac, E., Sellos, D., Watanabe, S., Tsukamoto, K., Otake, T. 2015. Stable Isotopic Composition of 15 Anguilliform Leptocephali and other Food Web Components from west of the Mascarene Plateau. Progress in Oceanography 137, 69-83.

Fowler, S.W., Knauer, G.A., 1986. Role of large particles in the transport of elements and organic compounds through the oceanic water column. Progress in Oceanography 16, $147-194$.

Fry, B., Arnold, C. 1982. Rapid 13C/12C turnover during growth of brown shrimp (Penaeus aztecus). Oecologia 54, 200-204.

Gannes, L.Z., Martínez del Rio, C., Koch, P. 1998. Natural abundance variations in stable isotopes and their potential uses in animal physiological ecology. Comparative Biochemistry and Physiology 119, 725-737.

Grob, C., Ulloa, O., Claustre, H., Huot Y., Alarcón, G., Marie, D. 2007 Contribution of picoplankton to the total particulate organic carbon concentration in the eastern South Pacific. Biogeosciences 4, 837-852.

Hanlon, R.T. 1987. Mariculture. In: P.R. Boyle (Editor), Cephalopod Life Cycles, 2. Academic Press, London, pp. 291-305.

Hannides, C.C.S., Popp, B.N., Choy, C.A., Drazen, J.C., 2013. Midwater zooplankton and suspended particle dynamics in the North Pacific Subtropical Gyre: a stable isotope perspective. Limnology and Oceanography 58, 1931-1946.

Hansen, B., Bjornsen, P.K., Hansen, P.J. 1994. The size ratio between planktonic predators and their prey. Limnology and Oceanography 39, 395-403.

Hays, G.C. 2003. A review of the adaptative significance et ecosystem consequences of zooplankton diel vertical migration. Hydrobiologia 503, 163-70.

Houssard, P., Lorrain, A., Tremblay-Boyer, L., Allain, V., Graham, B.S., Menkes, C.E., Pethybridge, H., Couturier, L., Point, D., Leroy, B., Receveur, A., Hunt, B.P.V., Vourey, E., Bonnet, S., Rodier, M., Raimbault, P., Feunteun, E., Kuhnert, P.M., Munaron, J-M, Lebreton, B., Otake T., Letourneur, L. 2017. Trophic position increases with thermocline depth in yellowfin and bigeye tuna across the Western and Central Pacific Ocean. Progress in Oceanography 154, 49-63.

Inoue, J.G., Miya, M., Tsukamoto, K., Nishida, M. 2004. Mitogenomic evidence for the monophyly of elopomorph fishes (Teleostei) and the evolutionary origin of the leptocephalus larva. Molecular Phylogeny and Evolution 32, 274-286. 
Kimura, S., Tsukamoto, K. 2006. The salinity front in the North Equatorial Current: A landmark for the spawning migration of the Japanese eel (Anguilla japonica) related to the stock recruitment. Deep-Sea Research II 53, 315-325.

Kiørboe, T. 2000. Colonization of marine snow aggregates by invertebrate zooplankton: abundance, scaling, and possible role. Limnology and Oceanography 45, 479-484.

Kiørboe, T. 2001. Formation and fate of marine snow: small-scale processes with large-scale implications. Scientia Marina 65, 57-71.

Kiørboe, T. 2011. How zooplankton feed: mechanisms, traits and trade-offs. Biological Reviews 86, 311-339.

Knapp, A. N., McCabe, K. M., Grosso, O., Leblond, N., Moutin, T., Bonnet, S. 2018 Distribution and rates of nitrogen fixation in the western tropical South Pacific Ocean constrained by nitrogen isotope budgets. Biogeosciences 15, 2619-2628

Last, J.M. 1978. The food of three species of gadoid larvae in the eastern English Channel and southern North Sea. Marine Biology 48, 377-386.

Leblanc, K., Cornet, V., Rimmelin-Maury, P., Grosso, O., Hélias-Nunige, S., Brunet, C., Claustre, H., Ras, J., Leblond, N., and Quéguiner, B. 2018. Silicon cycle in the tropical South Pacific: contribution to the global Si cycle and evidence for an active pico-sized siliceous plankton. Biogeosciences 15, 5595-5620

Li, Q., Wang, X., Liu, X., Jiao, N., and Wang, G. 2013. Abundance and novel lineages of thraustochytrids in Hawaiian waters. Microbial Ecology 66, 823-830.

Liénart, C., Feunteun, E., Miller, M.J., Aoyama, J., Mortillaro, J-M., Hubas, C., Kuroki, M., Watanabe, S., Dupuy, C., Carpentier, A., Otake, T., Tsukamoto, K., Meziane, T. 2016. Geographic variation in stable isotopic and fatty acid composition of anguilliform leptocephali and particulate organic matter in the South Pacific. Marine Ecology Progress Series 544, 225-241.

Lorenzen, C.J. 1967 Determination of chlorophyll and pheo-pigments: spectrophotometric equations 1. Limnology and Oceanography 12, 343-346.

Lorrain, A., Graham, B.S., Popp, B.N., Allain, V., Olson, R.J., Hunt, B.P.V., Potier, M., Fry, B., Galván-Magañaj, F., Menkes, C.E.R., Kaehler, S., Ménard, F. 2015. Nitrogen isotopic baselines and implications for estimating foraging habitat and trophic position of yellowfin tuna in the Indian and Pacific Oceans. Deep-Sea Research II 113, 188-198. Lundgreen, R.B.C., Jaspers, C., Traving, S.J., Ayala, D.J., Lombard, F., Grossart, H.P., Nielsen, T.G., Munk, P., Riemann, L. 2019. Eukaryotic and cyanobacterial communities 
associated with marine snow particles in the oligotrophic Sargasso Sea. Scientific Reports 9,8891 .

McGowan, J.A. 1974. The nature of oceanic ecosystems. The biology of the oceanic Pacific, 9-28.

Ménard, F., Lorrain, A., Potier, M., Marsac, F. 2007. Isotopic evidence of distinct feeding ecologies and movement patterns in two migratory predators (yellow-fin tuna and swordfish) of the western Indian Ocean. Marine Biology 153, 141-152.

Mehner, T., Schultz, H., Bauer, D., Herbst, R., Voigt, H., Benndorf, J. 1996. Intraguild predation and cannibalism in age-0 perch (Percafluviatilis) and age-0 zander (Stizostedion lucioperca): Interactions with zooplankton succession, prey fish availability and temperature. Annales Zoologici Fennici 33, 353-361.Menkes, C.E., Allain, V., Rodier, M., Gallois, F. and 11 others 2015. Seasonal oceanography from physics to micronekton in the south-west Pacific. Deep-Sea Research Part II: Topical Studies in Oceanography 113, 125.

Miller, M.J. 2009. Ecology of anguilliform leptocephali: remarkable transparent fish larvae of the ocean surface layer. Aqua-BioScience Monographs 2, 1-94.

Miller, M.J. 2015. Night time vertical distribution and regional species composition of eel larvae in the western Sargasso Sea. Regional Studies in Marine Science 1, 34-46.

Miller, M.J., McCleave, J.D. 1994. Species assemblages of leptocephali in the subtropical convergence zone of the Sargasso Sea. Journal of Marine Research 52, 743-772.

Miller, M.J., Tsukamoto, K. 2004. An introduction to leptocephali: Biology and identification. Ocean Research Institute, University of Tokyo.

Miller, M.J., Wouthuyzen, S., Minagawa, G., Aoyama, J., Tsukamoto, K. 2006a. Distribution and ecology of leptocephali of the congrid eel, Ariosoma scheelei, around Sulawesi Island, Indonesia. Marine Biology 148, 1101-1111

Miller, M.J., Aoyama, J., Mochioka, N., Otake, T., Castle, P.H.J., Minagawa, G., Inagaki, T., Tsukamoto, K. 2006b. Geographic variation in the assemblages of leptocephali in the western South Pacific. Deep-Sea Research I 53, 776-794.

Miller, M.J., Otake, T., Aoyama, J., Wouthuyzen, S., Suharti, S., Sugeha, H.Y., Tsukamoto, K. 2011. Observations of gut contents of leptocephali in the North Equatorial Current and Tomini Bay, Indonesia. Coastal Marine Science 35, 277-288.

Miller, M.J., Stepputtis, D., Bonhommeau, S., Castonguay, M., Schaber, M., Vobach, M., Hanel, R. 2013a. Comparisons of catches of large leptocephali using an IKMT and a large pelagic trawl in the Sargasso Sea. Marine Biodiversity 43, 493-501. 
Miller M.J., Chikaraishi Y., Ogawa N.O., Yamada Y., Tsukamoto K., Ohkouchi N. 2013b. A low trophic position of Japanese eel larvae indicates feeding on marine snow. Biology Letters 9, 20120826.

Miller, M.J., Feunteun, E., Aoyama, J., Watanabe, S., Kuroki, M., Lecomte-Finiger, R., Minegishi, Y., Robinet, T., Reveillac, E., Gagnaire, P.-A., Berrebi, P., Tsukamoto, K., Otake, T. 2015. Biodiversity of leptocephali west of the Mascarene Ridge in the southwestern Indian Ocean. Progress in Oceanography 137, 84-102.

Miller, M.J., Wouthuyzen, S., Feunteun, E., Aoyama, J., Watanabe, S., Syahailatua, A., Kuroki, M., Robinet, T., Hagihara, S., Otake, T., Tsukamoto, K. 2019a. Contrasting biodiversity of eel larvae across the central Indian Ocean subtropical gyre. Deep-Sea Research II 161: 120-131.

Miller, M. J., Marohn, L., Wysujack K., Freese M., Pohlmann J.-D., Westerberg H., Tsukamoto K., Hanel R. 2019b. Morphology and gut contents of anguillid and marine eel larvae in the Sargasso Sea. Zoologischer Anzeiger 279: 138-151.

Minagawa, M., Wada, E. 1984. Stepwise enrichment of $15 \mathrm{~N}$ along food chains: further evidence and the relation between $\delta 15 \mathrm{~N}$ and animal age. Geochimica et Cosmochimica Acta 48, 1135-1140.

Miyazaki, S., Kim, H.Y., Zenimoto, K., Kitagawa, T., Miller, M.J., Kimura, S. 2011. Stable isotope analysis of two species of anguilliform leptocephali (Anguilla japonica and Ariosoma major) relative to their feeding depth in the North Equatorial Current region. Marine Biology 158, 2555-2564.

Mochioka, N., Iwamizu, M. 1996. Diet of anguillid larvae: leptocephali feed selectively on larvacean houses and fecal pellets. Marine Biology 125, 447-452.

Moutin, T., Broeck, N.V.D., Beker, B., Dupouy, C., Rimmelin, P., Bouteiller, A.L., 2005. Phosphate availability controls Trichodesmium spp. biomass in the SW Pacific Ocean. Marine Ecology Progress Series 297, 15-21.

Moutin, T., Wagener, T., Caffin, M., Fumenia, A., Gimenez, A., Baklouti, M., BouruetAubertot, P., Pujo-Pay, M., Leblanc, K., Lefevre, D., Helias Nunige, S., Leblond, N., Grosso, O., and de Verneil, A. 2018. Nutrient availability and the ultimate control of the biological carbon pump in the western tropical South Pacific Ocean, Biogeosciences 15, 2961-2989.

Nelson, J.S. 2006. Fishes of the World. 4th edn.John Wiley and Sons, Hoboken, NJ. 
Onda H. 2017. Studies on the distribution and feeding ecology of Anguilliformes leptocephali in the North Equatorial Current of the western Pacific Ocean. $\mathrm{PhD}$ Dissertation. Atmosphere and Ocean Research Institute, University of Tokyo. pp. 153.

Onda, H., Miller, M.J., Takeshige, A., Miyake, Y., Kuroki, M., Aoyama, J., Kimura, S. 2017. Vertical distribution and assemblage structure of leptocephali in the North Equatorial Current region of the western Pacific. Marine Ecology Progress Series 575, 119-136.

Otake, T., Hirokawa, J. Fujimoto H, Imaizumi K. 1995. Fine structure et function of the gut epithelium of pike eel larvae. Journal of Fish Biology 47, 126-42.

Otake, T., Nogami, K., Maruyama, K. 1990. Possible food sources of leptocephali. La mer $28,218-224$.

Otake, T., Nogami, K., Maruyama, K., 1993. Dissolved and particulate organic matter as possible food sources for eel leptocephali. Marine Ecology Progress Series 92, 27-34

Otake, T., Inagaki, T., Hasumoto, H., Mochioka, N., Tsukamoto, K. 1998. Diel vertical distribution of Anguilla japonica leptocephali. Ichthyological Research 45, 208-211.

Passow, U., 2002. Transparent exopolymer particles (TEP) in aquatic environments Progress in Oceanography 55, 287-333.

Peterson, B.J., Fry, B. 1987. Stable isotopes in ecosystem studies. Annual Reviews of Ecology and Systematics 18, 293-320.

Pilskaln, C.H., Vilareal, T.A., Dennett, M., Darkangelo-Wood, C., Meadows, G. 2005. High concentrations of marine snow and diatom algal mats in the North Pacific Subtropical Gyre: implications for carbon and nitrogen cycles in the oligotrophic ocean. Deep-Sea Res. I 52, 2315-2332.

Pinnegar, J.K., Polunin, N.V.C. 1999. Differential fractionation of $\delta^{13} \mathrm{C}$ and $\delta^{15} \mathrm{~N}$ among fish tissues: implications for the study of trophic interactions. Functional Ecology 13, 225231.

Pomeroy, L.R., Deibel, D. 1980. Aggregation of organic matter by pelagic tunicates1. Limnology and Oceanography, 25, 643-652.

Post, D.M., Kitchell, J.F. 1997. Trophic ontogeny and life history effects on interactions between age-0 fishes and zooplankton. Ergebnisse der Limnologie 49, 1-12.

Post, D.M. 2002. Using stable isotopes to estimate trophic position: models. Methods and assumptions. Ecology 83, 703-718.

Quattrini, A.M., McClain-Counts, J., Artabane, S.J., Roa-Varon, A., McIver, T.C., Rhode, M., Ross, S.W. 2019. Assemblage structure, vertical distributions, and stable isotopic 
compositions of anguilliform leptocephali in the Gulf of Mexico. Journal of Fish Biology.

Rau, G.H., Anderson, N.H., 1981. Use of 13C/12C to trace dissolved and particulate organic matter utilization by populations of an aquatic invertebrate. Oecologia 48, 19-21.

Riemann, L., Alfredsson, H., Hansen, M.M.., Als, T.D., Nielsen, T.G., Munk, P., Aarestrup, K. 2010. Qualitative Assessment of the Diet of European Eel Larvae in the Sargasso Sea Resolved by DNA Barcoding. Biology Letters 6, 819-22.

Rii, Y.M., Karl, D.M., Church, M.J. 2016. Temporal and vertical variability in picophytoplankton primary productivity in the North Pacific Subtropical Gyre. Marine Ecology Progress Series 562, 1-18.

Samuelsson, K. Andersson, A. 2003. Predation limitation in the pelagic microbial food web in an oligotrophic aquatic system. Aquatic Microbiology and Ecology 30, 239-250.

Schnetzer, A., Steinberg, D.K. 2002. Active transport of particulate organic carbon and nitrogen by vertically migrating zooplankton in the Sargasso Sea. Marine Ecology Progress Series 234, 71-84.

Shanks, A.L., Walters, K. 1997. Holoplankton, meroplankton, and meiofauna associated with marine snow. Marine Ecology Progress Series 156, 75-86.Simon, M., Grossart, H., Schweitzer, B., Ploug, H. 2002. Microbial ecology of organic aggregates in aquatic ecosystems. Aquatic Microbial Ecology 28, 175-211.

Smith, D. G. 1989. Introduction to leptocephali. In: Böhlke EB (ed). Fishes of the Western North Atlantic. Leptocephali. Part 9, Vol. 2. Sears Foundation for Marine Research, New Haven.

Somes, C.J., Schmittner, A., Galbraith, E.D., Lehmann, M.F., Altabet, M.A., Montoya, J.P., Letelier, R.M., Mix, A.C., Bourbonnais, A., Eby, M. 2010. Simulating the global distribution of nitrogen isotopes in the ocean. Global Biogeochemical Cycles 24.

Strickland, J.D.H. and T.R. Parsons. 1972. A practical handbook of seawater analysis. Fisheries Research Board of Canada. Canada. 328 p.

Tabeta, O., Mochioka, N. 1988. Leptocephali. In: Okiyama M (ed). An Atlas of the Early Stage Fishes in Japan. Tokai University Press, Tokyo; pp. 15-64 (in Japanese).

Tanaka, H., Kagawa, H., Ohta, H., Okuzawa, K., Hirose, K. 1995. The first report of eel larvae ingesting rotifers. Fisheries Science 61, 171-2. 
Tarling, G.A. 2003. Sex-dependent diel vertical migration in northern krill Meganyctiphane norvegica and its consequences for population dynamics. Marine Ecology Progress Series 260, 173-188.

Terazaki, M., Marumo, R. 1982. Feedings habits of mesopelagic and bathypelagic chaetognatha, sagitta-zetesios fowler. Oceanologica Acta, 5, 461-464.

Thingstad, T.F., Rassoulzadegan, F. 1995. Nutrient limitations, microbial food webs, and biological C-pumps": Suggested interactions in a P-limited Mediterranean. Marine Ecology Progress Series 117, 299-306.

Tomoda, T., Kurogi, H., Okauchi, M., Kamoshida, M., Imaizumi, H., Jinbo, T., Nomura, K., Furuita, H., Tanaka, H. 2015. Hatchery-reared Japanese eel Anguilla japonica larvae ingest various organic matters formed part of marine snow. Nippon Suis. Gakk. 81, 715-721 (in Japanese with English abstract).

Tomoda, T., Chow, S., Kurogi, H., Okazaki, M., Ambe, D., Furuita, H., Matsunari, H., Nagai, S., Yokouchi, K., Nomura, K., Tanaka, H., Hasegawa, D., Inaba, N. 2018. Observations of gut contents of anguilliform leptocephali collected in the western North Pacific. Nippon Suis. Gakk. 84, 32-44. (in Japanese with English abstract)

Turner, J.T. 2002. Zooplankton fecal pellets, marine snow and sinking phytoplankton blooms. Aquat. Microbial Ecol. 27, 57-102.

Van Wambeke, F., Gimenez, A., Duhamel, S., Dupouy, C., Lefevre, D., Pujo-Pay, M., and Moutin, T. 2018. Dynamics and controls of heterotrophic prokaryotic production in the western tropical South Pacific Ocean: links with diazotrophic and photosynthetic activity. Biogeosciences 15, 2669-2689.

Waite, A.M., Muhling, B.A., Holl, C.M., Beckley, L.E., Montoya, J.P., Strzelecki, J., Thompson, P.A., Pesant, S. 2007. Food web structure in two counter-rotating eddies based on $\delta 15 \mathrm{~N}$ and $\delta 13 \mathrm{C}$ isotopic analyses. Deep-Sea Research II 54, 1055-1075.

Williams, R., Wakeham, S., McKinney, R., Wishner, K.F. 2014. Trophic ecology and vertical patterns of carbon and nitrogen stable Isotopes in zooplankton from oxygen minimum zone regions. Deep-Sea Research I 90, 36-47.

Yamaguchi, A., Watanabe, Y., Ishida, H., Harimoto, T., Furusawa, K., Suzuki, S., Ishizaka, J., Ikeda, T., Takahashi, M.M. 2004. Latitudinal Differences in the Planktonic Biomass and Community Structure Down to the Greater Depths in the Western North Pacific. Journal of Oceanography 60, 773-787. 
Zhang, Y., Jiao, N., Hong, N. 2008. Comparative study of picoplankton biomass and community structure in different provinces from subarctic to subtropical oceans. Deep Sea Research Part II 55, 1605-1614. 
Table 1. Measured values of nutrients $\left(\mu \mathrm{g} \mathrm{L}^{-1}\right)$ within the maximum fluorescence depth layer at individual stations within the South Equatorial Countercurrent (SECC), South Equatorial Current (SEC), and South Tropical Countercurrent (STCC) current zones shown in Figure 1. The geographic location of some stations is indicated as northeast (NE), southwest (SW) etc.

\begin{tabular}{|c|c|c|c|c|c|}
\hline $\begin{array}{l}\text { Currents/ } \\
\text { Stations }\end{array}$ & $\mathrm{NO}_{3}$ & $\mathrm{NO}_{2}$ & $\mathrm{PO}_{4}$ & $\mathrm{Si}(\mathrm{OH})_{4}$ & $\mathrm{NH}_{4}$ \\
\hline \multicolumn{6}{|l|}{ SECC } \\
\hline St 44 & 127.8 & 19.1 & 65.1 & 137.5 & 19.3 \\
\hline St 47 & 155.3 & 11.0 & 77.8 & 109.0 & 14.3 \\
\hline St 63 (NE) & 4.7 & 0.0 & 27.1 & 91.9 & 10.4 \\
\hline Mean \pm S.D. & $95.9 \pm 80.2$ & $10.1 \pm 9.6$ & $56.7 \pm 26.4$ & $112.8 \pm 23.1$ & $14.7 \pm 4.5$ \\
\hline \multicolumn{6}{|l|}{ SEC } \\
\hline St 39 & 28.3 & 4.7 & 44.8 & 512.6 & 12.9 \\
\hline St 41 & 45.3 & 2.4 & 44.9 & 76.0 & 20.6 \\
\hline St 49 & 3.5 & 0.3 & 29.3 & 67.9 & 9.5 \\
\hline St 51 & 11.7 & 2.8 & 42.5 & 88.4 & 19.4 \\
\hline St $60(\mathrm{E})$ & 9.7 & 1.9 & 34.9 & 63.9 & 25.7 \\
\hline Mean \pm S.D. & $19.7 \pm 17.0$ & $2.4 \pm 1.6$ & $39.3 \pm 6.9$ & $161.8 \pm 196.3$ & $17.6 \pm 6.4$ \\
\hline St 36 (SW) & 15.3 & 2.4 & 31.1 & 99.9 & 15.3 \\
\hline St 55 & 21.2 & 2.9 & 33.2 & 61.2 & 17.3 \\
\hline St 56 (SE) & 29.0 & 7.5 & 31.5 & 70.2 & 11.7 \\
\hline Mean \pm S.D. & $21.8 \pm 6.9$ & $4.3 \pm 2.8$ & $31.9 \pm 1.1$ & $77.1 \pm 20.2$ & $14.8 \pm 2.9$ \\
\hline
\end{tabular}


Figures
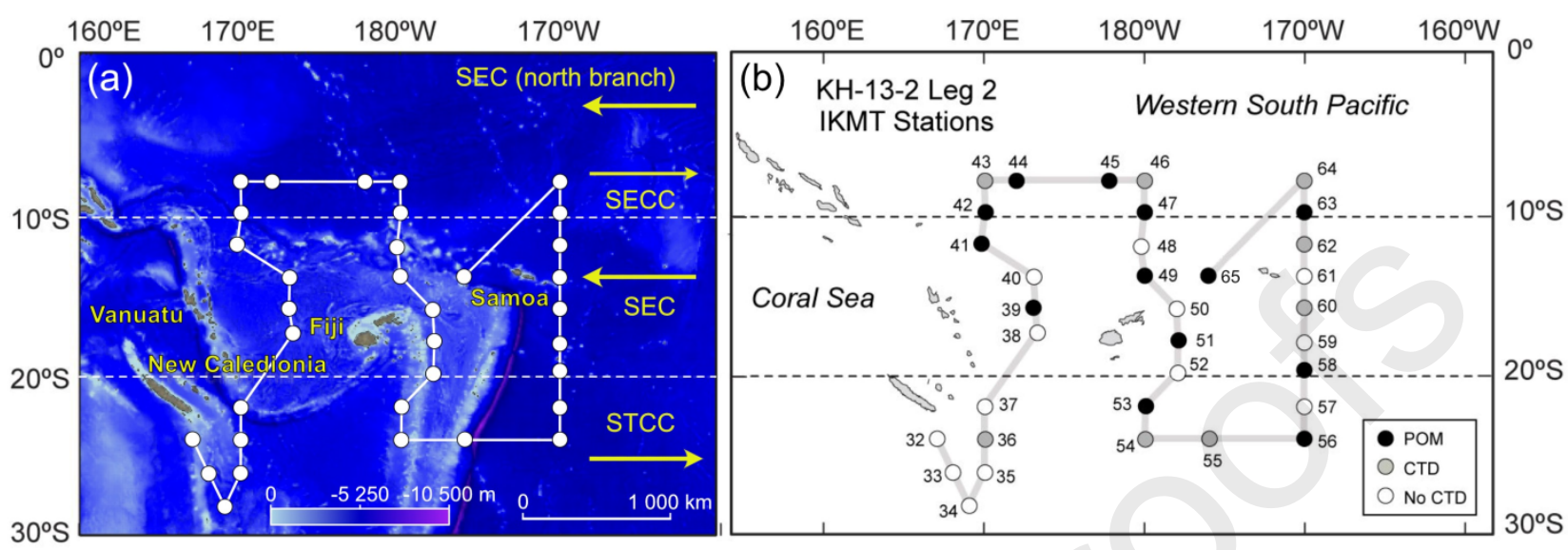

Figure 1. Maps of the KH-13-2 sampling survey of the R/V Hakuho Maru in February 2013 in relation to bathymetry and major current systems (a) and showing the IKMT stations for collecting leptocephali and other organisms, the station numbers (St. 32-65), CTD stations where particulate organic matter (POM) was collected (dark circles), and where other CTD casts made (grey circles) (b). Water samples for microbial loop functioning experiments were collected at stations 39, 41, 47, 49, 51 and 55. Darker colors indicate deeper areas (mid-range blues about 2000-3000 m, dark blues about 4000-5000 m) and lighter colors shallow areas (white about $500 \mathrm{~m}$ or less) in (a). 


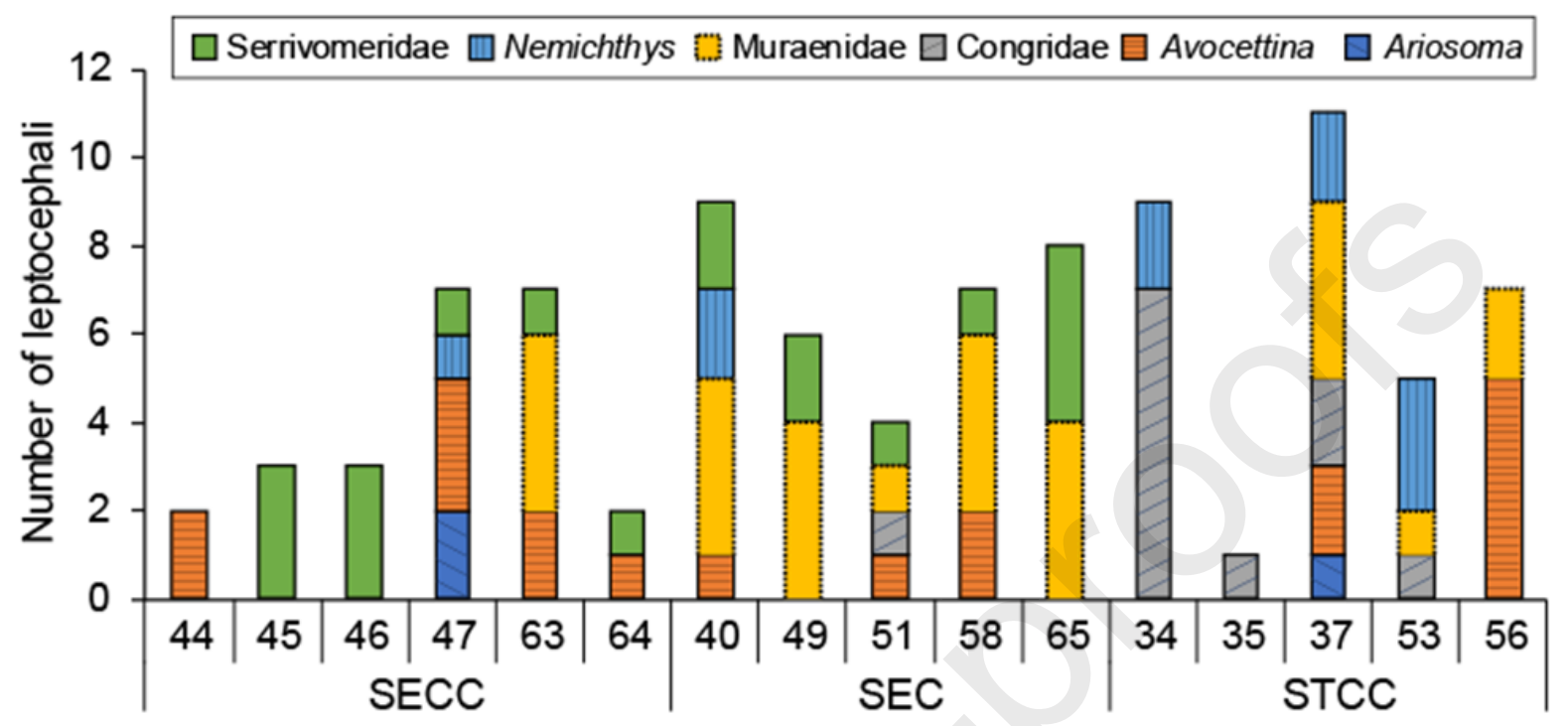

Figure 2. Number of 6 taxa of leptocephali that were analyzed for their isotopic signatures during the R/V Hakuho Maru cruise at each station within the 3 current zones of South Equatorial Countercurrent (SECC), South Equatorial Current (SEC), and South Tropical Countercurrent (STCC). 


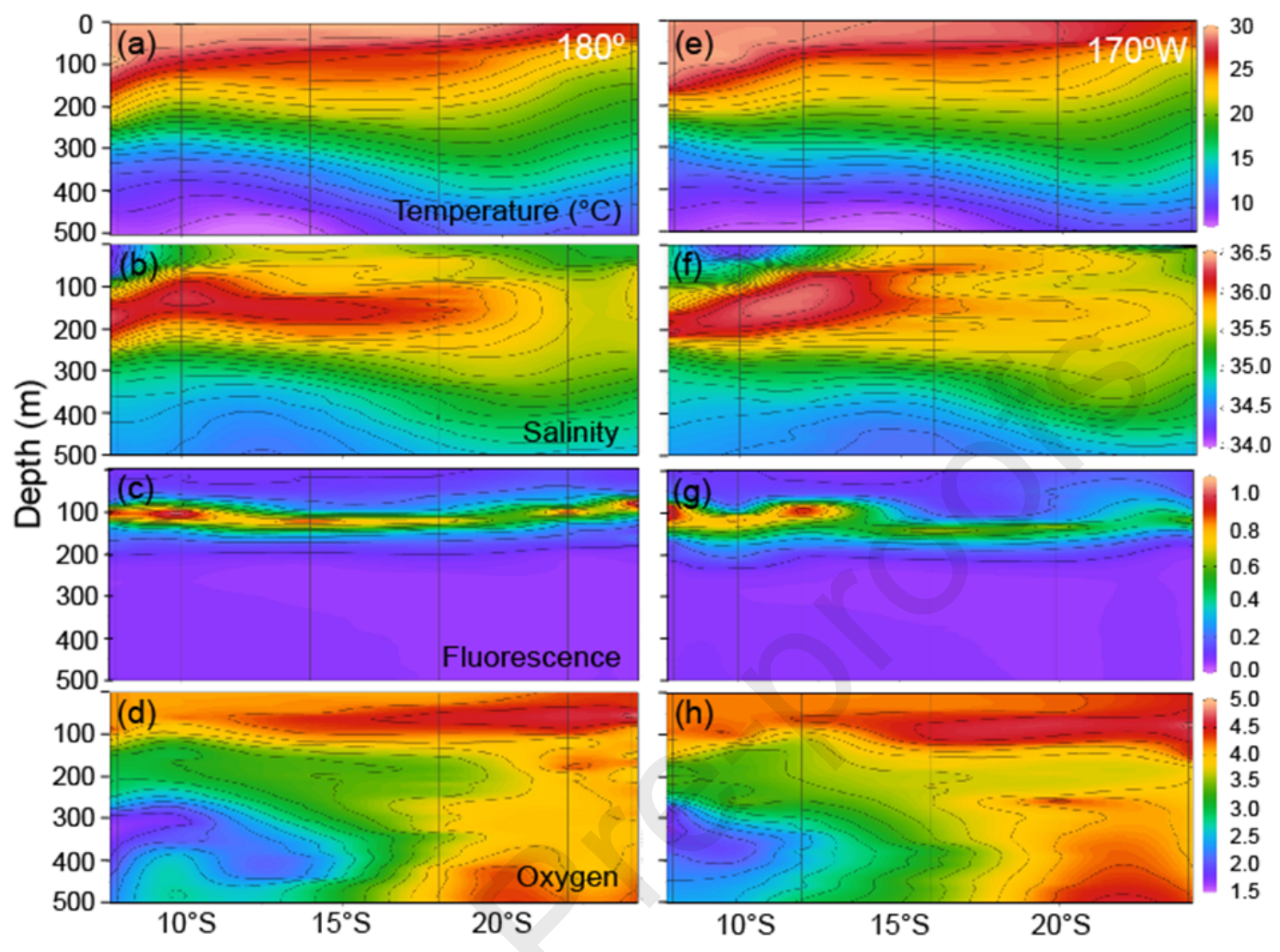

Figure 3. Hydrographic sections plotted from the CTD data from stations along or near $180^{\circ}$ (middle transect) and $170^{\circ} \mathrm{W}$ (eastern transect) for different parameters measured in the upper $500 \mathrm{~m}$. 


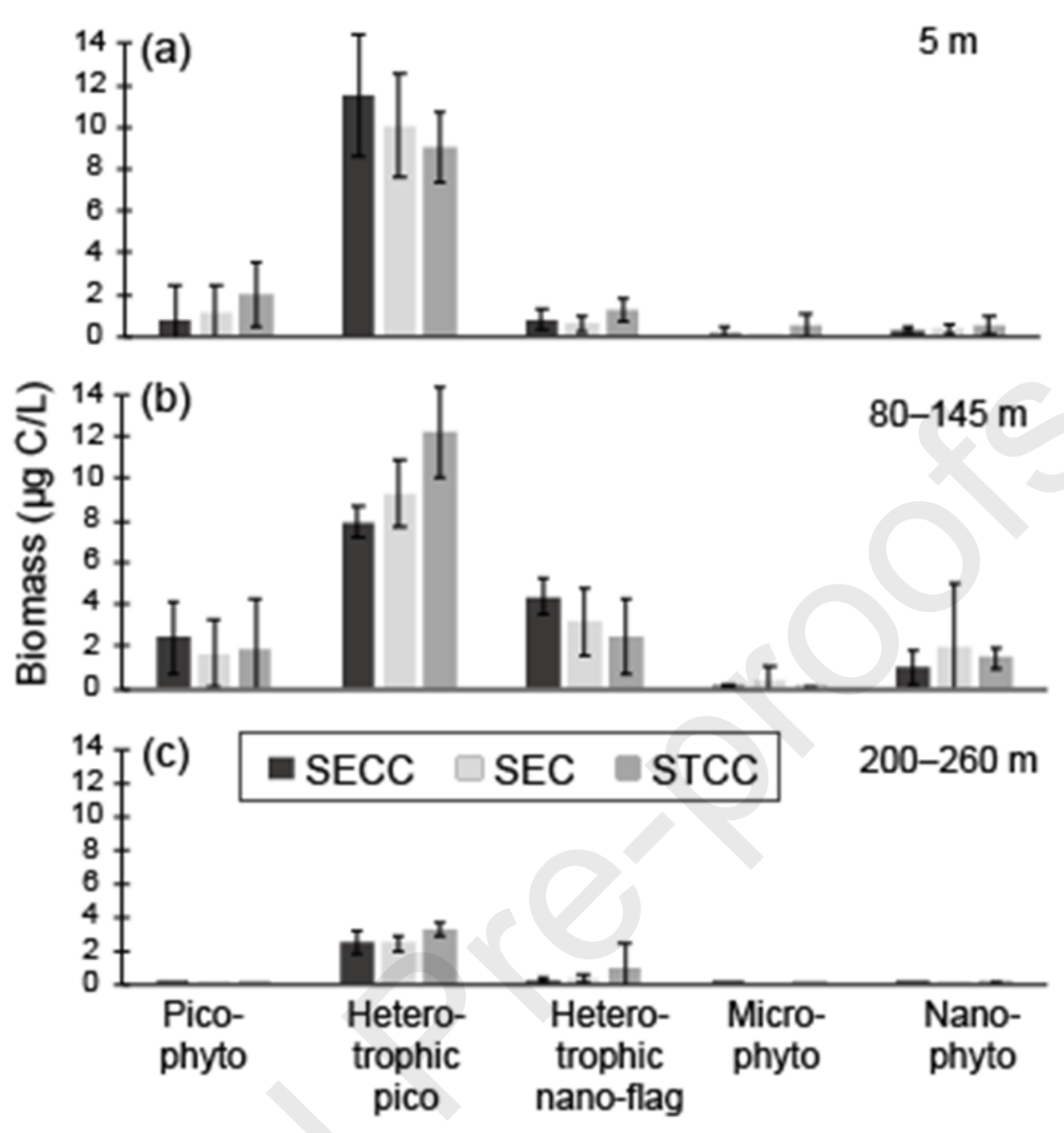

Figure 4. Biomass ( $\left.\mu \mathrm{g} \mathrm{C} . \mathrm{L}^{-1} \pm \mathrm{SD}\right)$ of the major groups and size categories of planktonic organisms contributing to POM at 3 depths in the 3 current zones of the South Equatorial Countercurrent (SECC), South Equatorial Current (SEC), and South Tropical Countercurrent (STCC). 


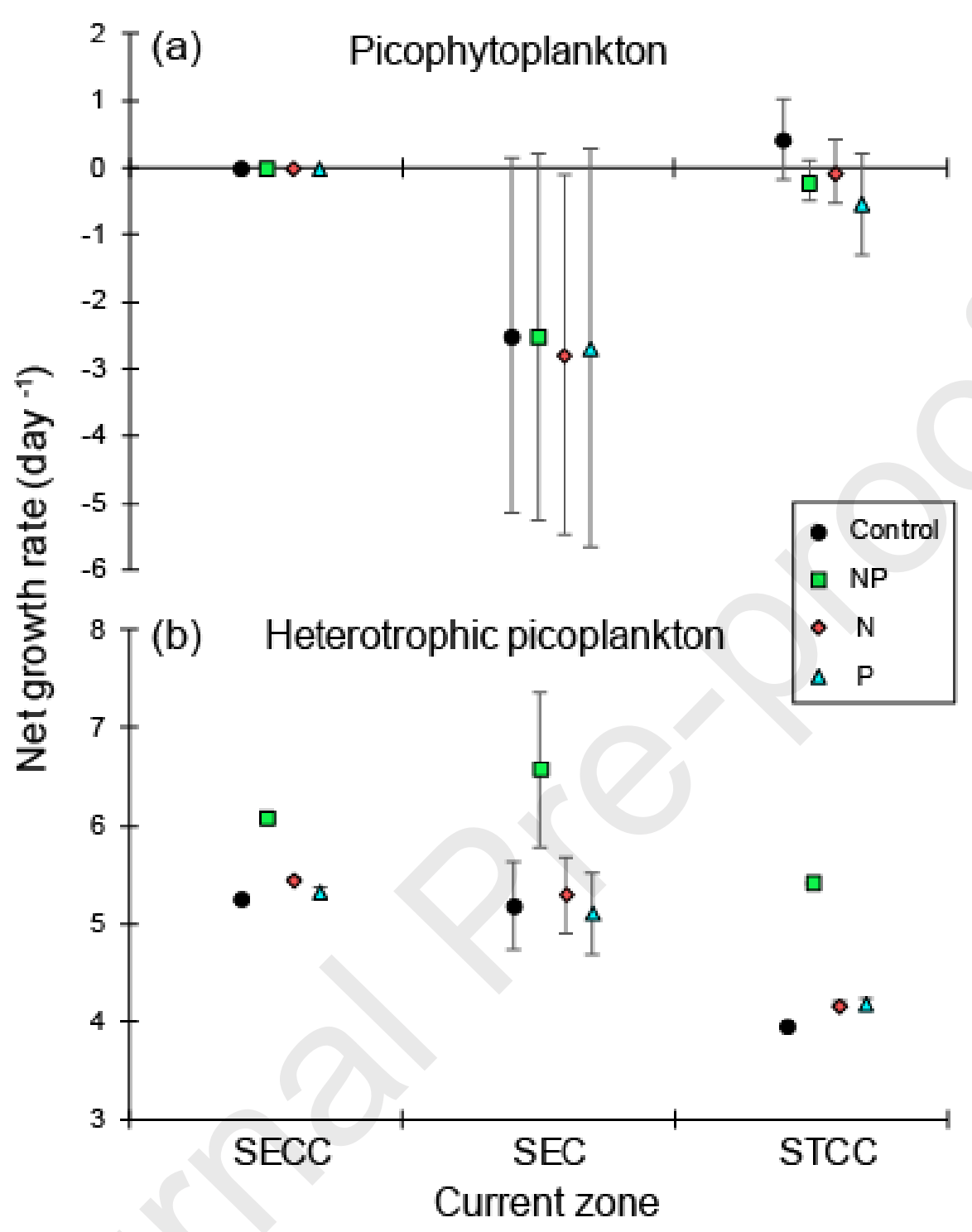

Figure 5. Net growth rate $\left(\right.$ day $\left.^{-1} \pm \mathrm{SD}\right)$ of (a) picophytoplankton and (b) heterotrophic picoplankton with the addition of inorganic nitrogen $(\mathrm{N})$, inorganic phosphorus $(\mathrm{P})$ and a combination of nitrogen and phosphorus (NP) and a control (no additions) using water from the 3 current zones of the South Equatorial Countercurrent (SECC), South Equatorial Current (SEC), and South Tropical Countercurrent (STCC) at the maximum fluorescence depth. 


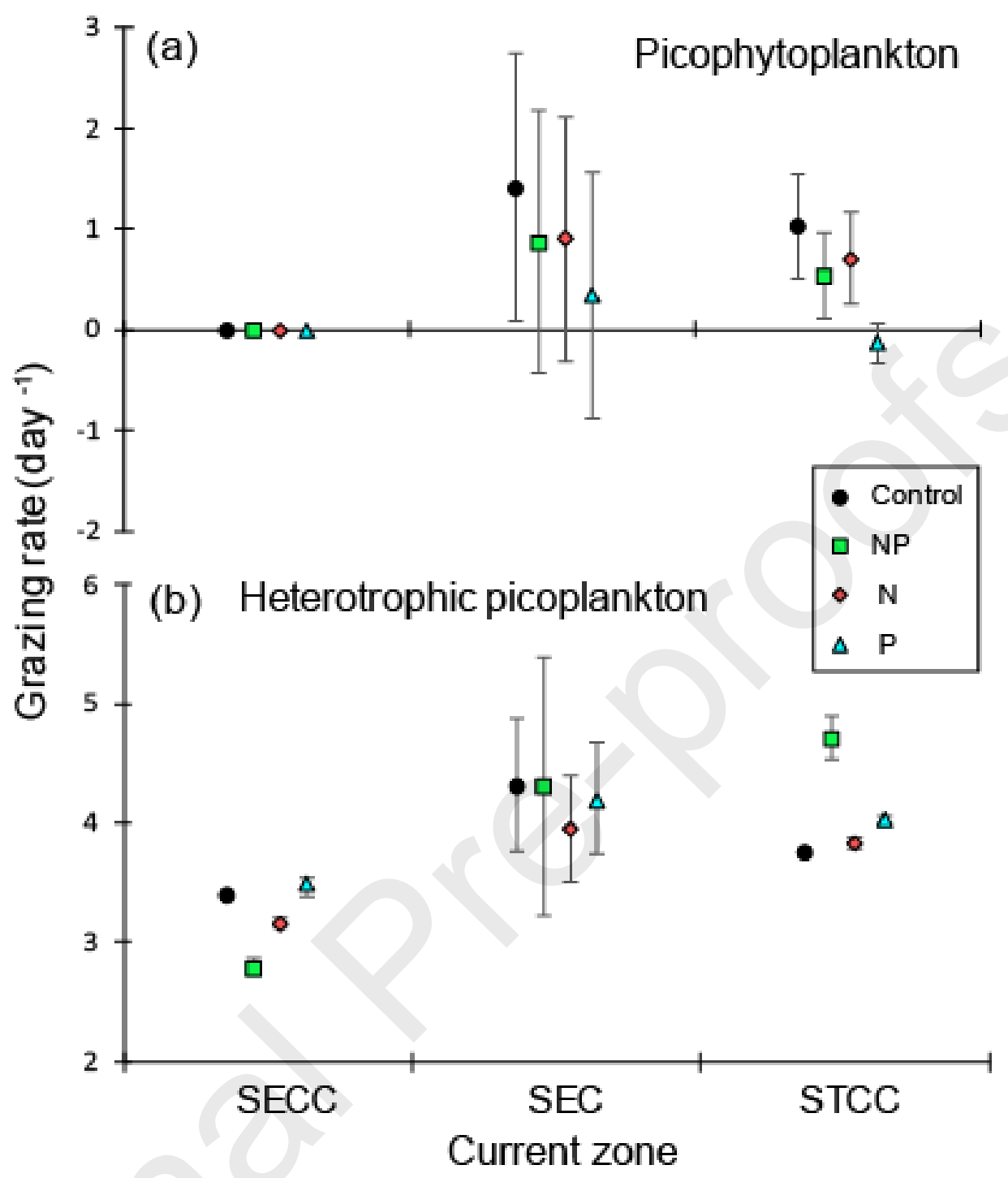

Figure 6. Grazing rate $\left(\right.$ day $\left.^{-1} \pm \mathrm{SD}\right)$ of (a) picophytoplankton and (b) heterotrophic picoplankton with the addition of inorganic nitrogen $(\mathrm{N})$, inorganic phosphorus $(\mathrm{P})$ and a combination of nitrogen and phosphorus (NP) and a control (no additions) using water from the 3 current zones of the South Equatorial Countercurrent (SECC), South Equatorial Current (SEC), and South Tropical Countercurrent (STCC) at the maximum fluorescence depth. 


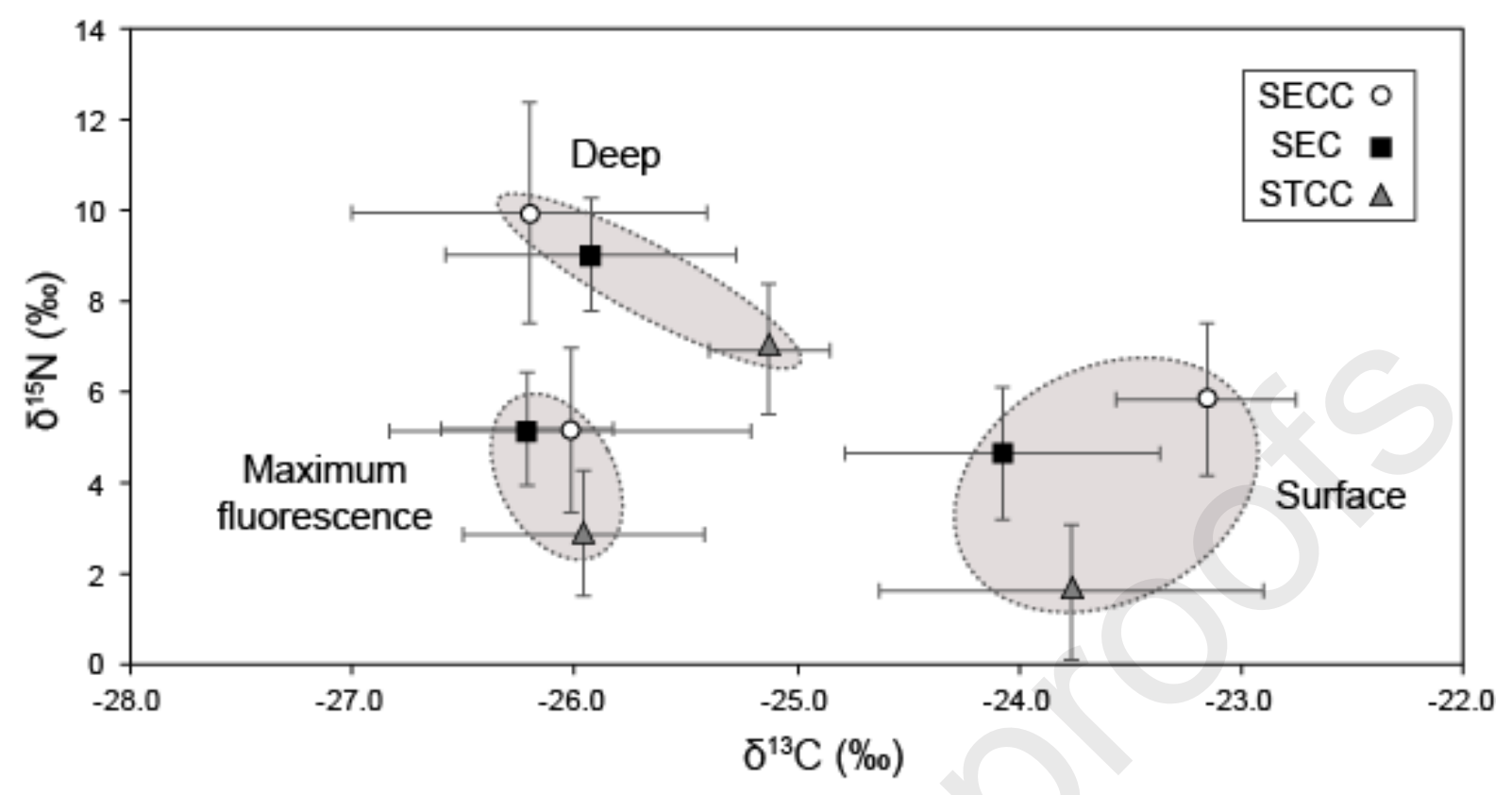

Figure 7. Mean carbon and nitrogen stable isotope values (\%o $\pm \mathrm{SD})$ of POM at different depths (depending on stations) from the 3 current zones of the South Equatorial Countercurrent (SECC), South Equatorial Current (SEC), and South Tropical Countercurrent (STCC). Grey shaded ovals highlight the distribution of mean values at the 3 POM sampling depths. 

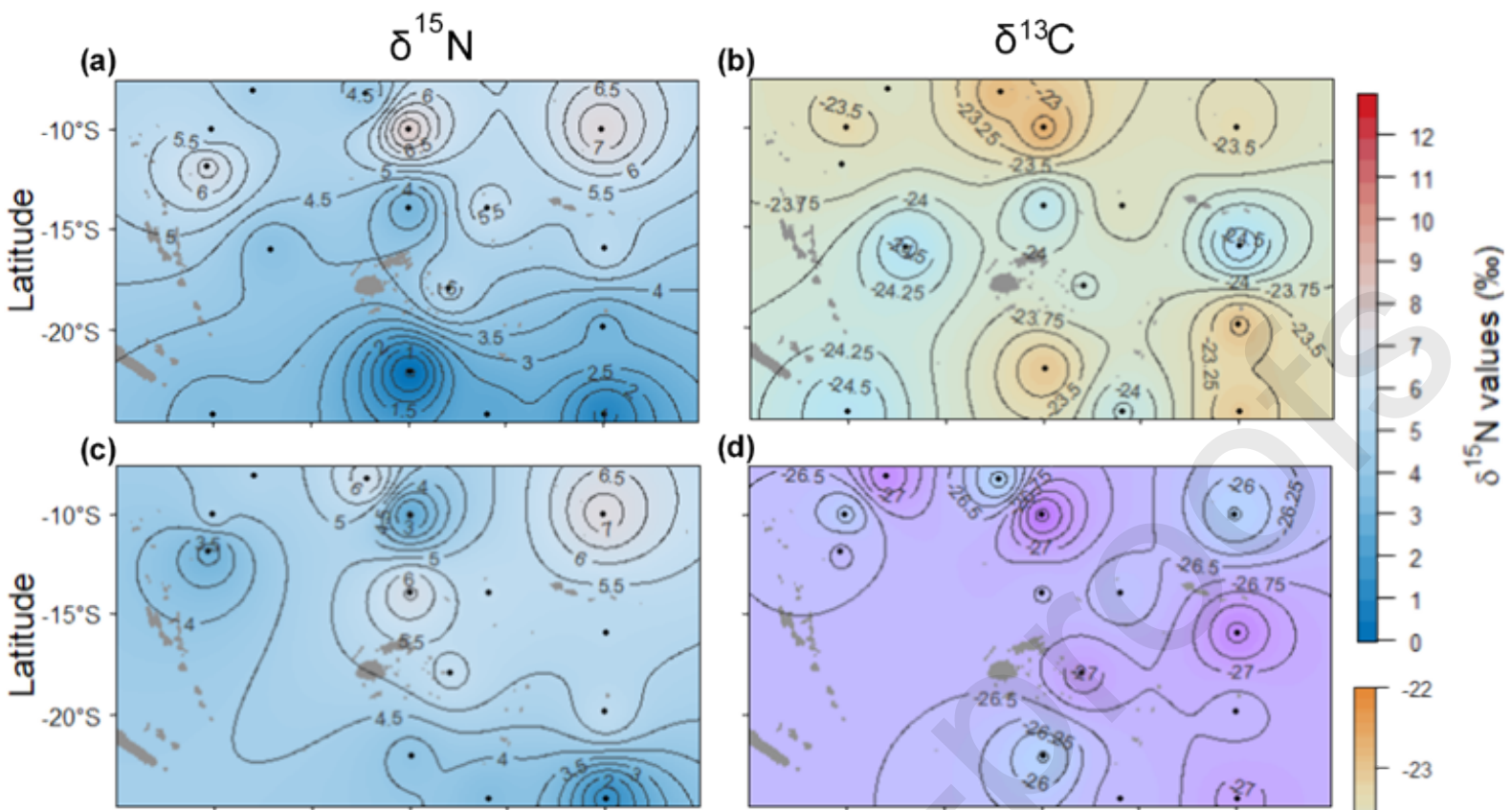

(d)
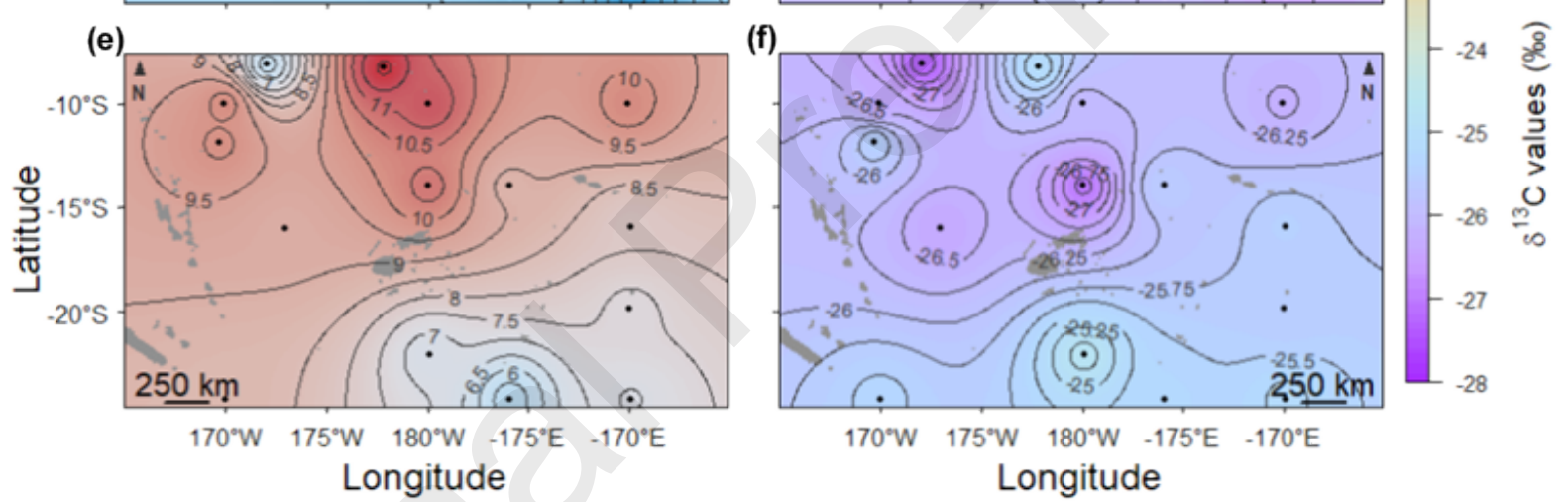

Figure 8. Contour plots of $\delta^{15} \mathrm{~N}$ (left panels) and $\delta^{13} \mathrm{C}$ (right panels) isotope values (Inverse Distance Weighted Interpolation, distance coefficient $=2)$ of POM at the surface $(5 \mathrm{~m}, \mathbf{a}$ and $\mathbf{b})$, maximum fluorescence ( $80-145 \mathrm{~m}, \mathbf{c}$ and d) and at the bottom $(200-260$, e and f) in the western South Pacific Ocean during the KH-13-2 cruise (February 2013, southern summer). The dots represent POM sampling stations, blue or purple colors show lower isotopic signatures than red or orange colors for $\delta^{15} \mathrm{~N}$ and $\delta^{13} \mathrm{C}$, respectively. The observed $\delta^{15} \mathrm{~N}$ values range from 0 to $12.1 \%$ and from -27.3 to $22.7 \%$ for $\delta^{13} \mathrm{C}$ values. 

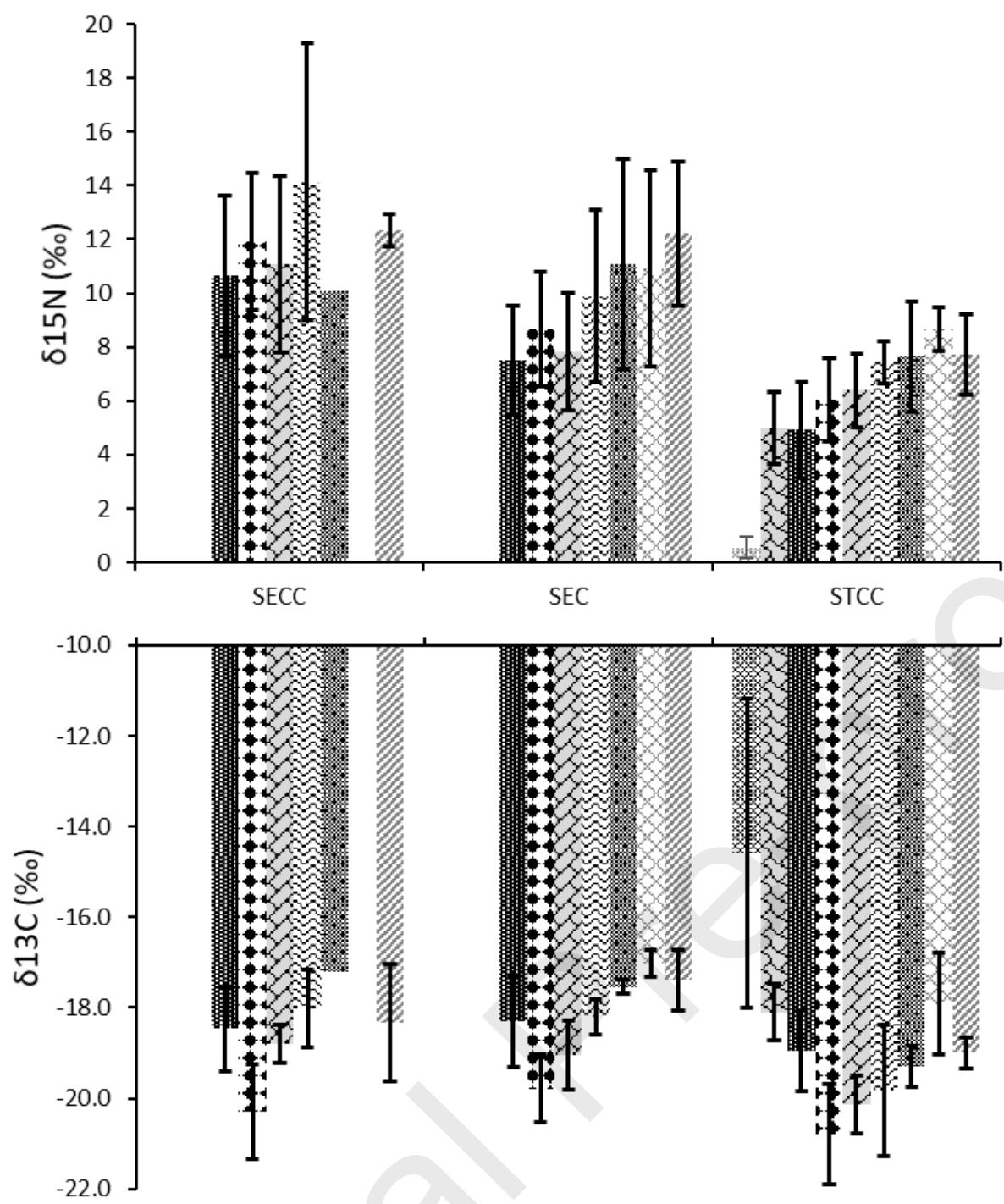

Trichodesmium

s Tuna larvae

Fish larvae

- Copepoda

¿ Euphausiidae

忩 Myctophidae

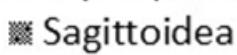

Polychaeta

\% Cephalopoda

Figure 9. Mean carbon and nitrogen stable isotope values (\%o \pm SD) of different taxa of meso- and macro-zooplankton, micronekton and the cyanobacterium Trichodesmium. 

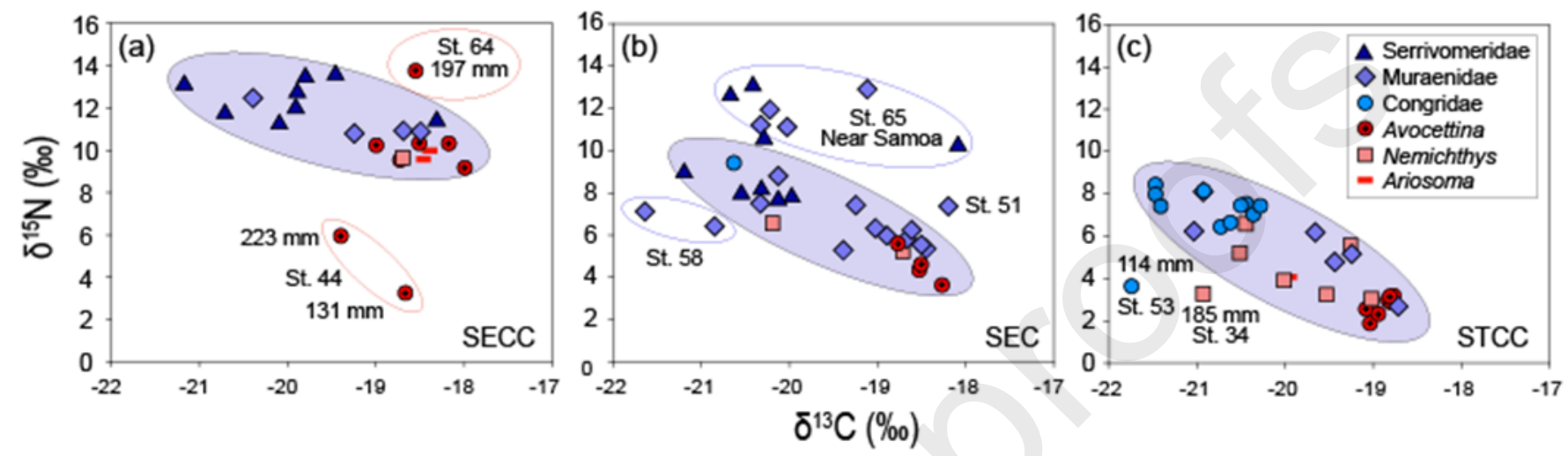

Figure 10. Mean carbon and nitrogen stable isotope values (\%o \pm SD) of different taxa of leptocephali from the 3 current zones of the South Equatorial Countercurrent (SECC), South Equatorial Current (SEC), and South Tropical Countercurrent (STCC). Shaded ovals highlight the main group of signatures for comparison among current zones and some larvae from individual stations are indicated by open ovals. The points of Group 1 leptocephali are shown in blue shades and Group 2 with red shades. 

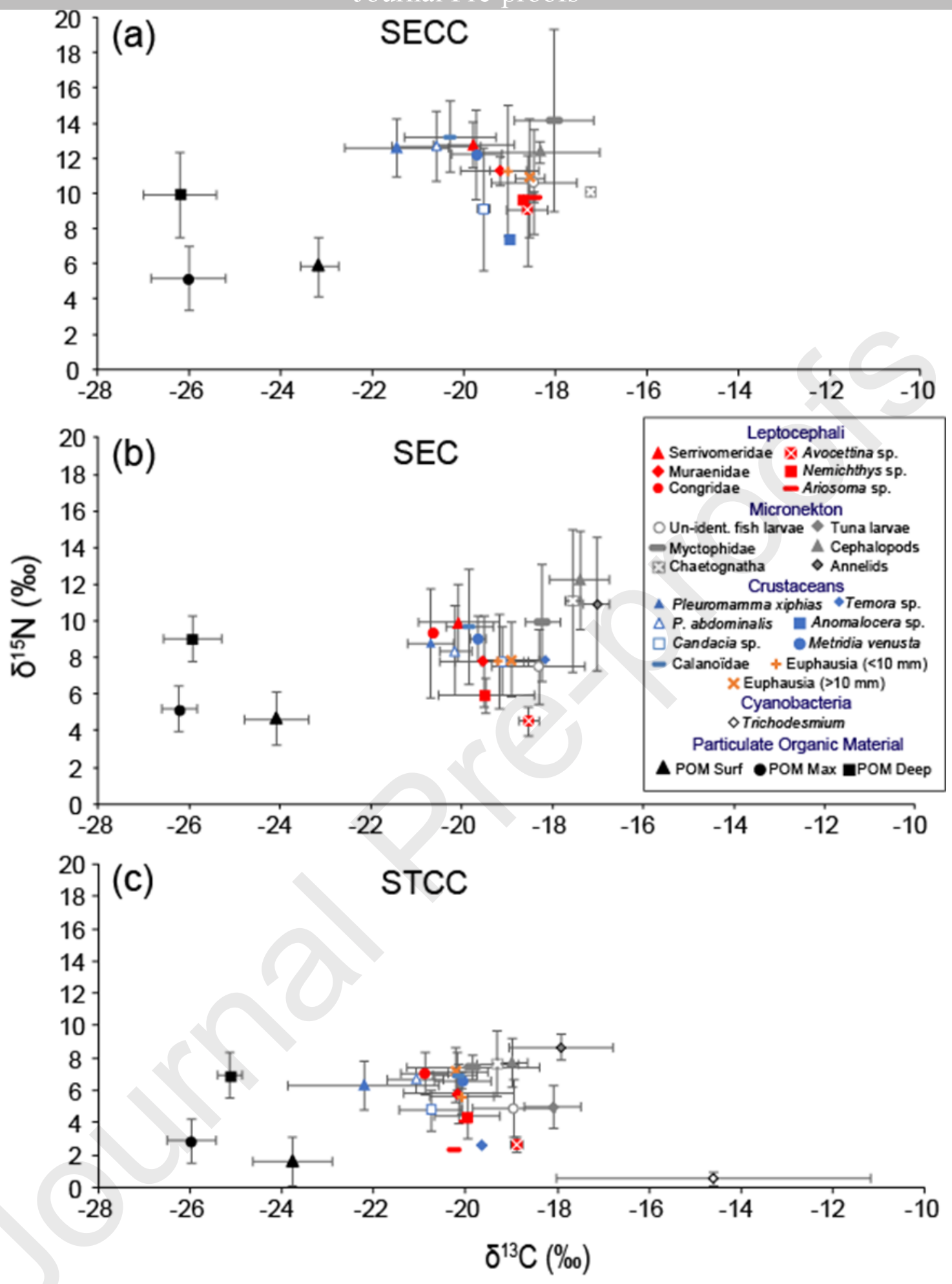

Figure 11. Mean carbon and nitrogen stable isotope values (\%o $\pm \mathrm{SD})$ of different taxa of leptocephali (red), meso- and macro-zooplankton, micronekton and POM at different depths from the 3 current zones of the South Equatorial Countercurrent (SECC), South Equatorial Current (SEC), and South Tropical Countercurrent (STCC). 
Supplementary table. Values of carbon and nitrogen stabie isotope values (\%o \pm SD) Or dirferent taxa or reptocepnall, meso- and macro-zooplankton, micronekton and POM at different depths within the 3 current zones of the South Equatorial Countercurrent (SECC), South Equatorial Current (SEC), and South Tropical Countercurrent (STCC).

\begin{tabular}{|c|c|c|c|c|c|c|c|c|c|c|c|c|c|c|c|c|}
\hline & \multirow[b]{2}{*}{ Taxonomic groups } & \multicolumn{5}{|c|}{ SECC } & \multicolumn{5}{|c|}{ SEC } & \multicolumn{5}{|c|}{ STCC } \\
\hline & & $\mathrm{N}$ & $\begin{array}{c}\delta 15 \mathrm{~N} \\
\text { mean } \pm S . D\end{array}$ & $\delta 15 N$ range & $\begin{array}{c}\delta 13 C \\
\text { mean } \pm S . D\end{array}$ & $\delta 13 \mathrm{C}$ range & $\mathrm{N}$ & $\begin{array}{c}\delta 15 \mathrm{~N} \\
\text { mean } \pm S . D\end{array}$ & $\delta 15 \mathrm{~N}$ range & $\begin{array}{c}\delta 13 C \\
\text { mean } \pm S . D\end{array}$ & $\delta 13 \mathrm{C}$ range & $\mathrm{N}$ & $\begin{array}{c}\delta 15 \mathrm{~N} \\
\text { mean } \pm \text { S.D }\end{array}$ & $\begin{array}{l}\delta 15 \mathrm{~N} \\
\text { range }\end{array}$ & $\begin{array}{c}\delta 13 C \\
\text { mean } \pm S . D\end{array}$ & $\delta 13 \mathrm{C}$ range \\
\hline \multicolumn{17}{|l|}{ Leptocephali } \\
\hline \multirow{2}{*}{ Nemichthyidae } & Nemichthys & 1 & 9.6 & - & -18.7 & - & 2 & $5.9 \pm 0.9$ & $5.2-6.6$ & $-19.5 \pm 1.0$ & $-20.2--18.7$ & 7 & $4.4 \pm 1.4$ & $3.0-6.6$ & $-20.0 \pm 0.7$ & $-20.9--19.0$ \\
\hline & Avocettina & 8 & $9.0 \pm 3.2$ & $3.2-13.7$ & $-18.6 \pm 0.4$ & $-19.4--18.0$ & 4 & $4.5 \pm 0.8$ & $3.6-5.6$ & $-18.5 \pm 0.2$ & $-18.8--18.3$ & 7 & $2.7 \pm 0.5$ & $1.8-3.1$ & $-18.9 \pm 0.1$ & $-19.1--18.8$ \\
\hline Serrivomeridae & & 9 & $12.7 \pm 1.3$ & $11.2-15.3$ & $-19.8 \pm 0.9$ & $-21.2--18.3$ & 10 & $9.9 \pm 2.1$ & 7.7-13.1 & $-20.1 \pm 0.9$ & $-21.2--18.1$ & 0 & - & - & - & - \\
\hline \multirow[t]{3}{*}{ Muraenidae } & & 4 & $11.3 \pm 0.8$ & $10.8-12.5$ & $-19.2 \pm 0.9$ & $-20.4--18.5$ & 17 & $7.8 \pm 2.5$ & $5.3-12.9$ & $-19.5 \pm 1.0$ & $-21.6--18.2$ & 7 & $5.8 \pm 1.8$ & $2.7-8.1$ & $-20.2 \pm 1.2$ & $-22.0--18.7$ \\
\hline & Conger & 0 & - & - & - & - & 1 & 9.4 & - & -20.6 & - & 6 & $7.4 \pm 0.6$ & $6.6-8.1$ & $-20.7 \pm 0.4$ & $-21.5--20.3$ \\
\hline & Gnathophis & 0 & - & - & - & - & 0 & - & - & - & - & 2 & $7.9 \pm 0.7$ & $7.4-8.4$ & $-21.4 \pm 0.0$ & $-21.5--21.4$ \\
\hline \multirow[t]{3}{*}{ Congridae } & Gorgasia & 0 & - & - & - & - & 0 & - & - & - & - & 2 & $6.9 \pm 0.7$ & $6.4-7.4$ & $-20.6 \pm 0.2$ & $-20.7--20.5$ \\
\hline & Ariosoma sp. & 2 & $9.8 \pm 0.3$ & $9.6-10.0$ & $-18.5 \pm 0.1$ & $-18.5--18.4$ & 0 & - & - & & - & 1 & 4.1 & - & -20.0 & - \\
\hline & Bathycongrus & 0 & - & - & - & - & 0 & - & - & & - & 1 & 3.6 & - & -21.7 & - \\
\hline \multicolumn{17}{|l|}{ Micronekton } \\
\hline & Polychaeta & 0 & - & - & - & - & 2 & $10.9 \pm 3.6$ & $8.4-13.5$ & $-17.0 \pm 0.3$ & $-17.2--16.8$ & 3 & $8.7 \pm 0.8$ & $8.1-9.6$ & $-17.9 \pm 1.1$ & $-19.2--17.0$ \\
\hline & Cephalopoda & 2 & $12.4 \pm 0.6$ & $11.9-12.8$ & $-18.3 \pm 1.3$ & $-19.2--17.4$ & 2 & $12.2 \pm 2.7$ & $10.3-14.1$ & $-17.4 \pm 0.7$ & $-17.9--16.9$ & 4 & $7.7 \pm 1.5$ & $6.3-9.7$ & $-19.0 \pm 0.3$ & $-19.2--18.5$ \\
\hline & Sagittoidea & 1 & $10.1 \pm-$ & & $-17.2 \pm-$ & & 3 & $11.1 \pm 4.0$ & $8.3-15.6$ & $-17.5 \pm 0.2$ & $-17.6--17.4$ & 3 & $7.6 \pm 2.0$ & $5.9-9.9$ & $-19.3 \pm 0.5$ & $-19.8--19.0$ \\
\hline & Myctophidae & 4 & $14.1 \pm 5.1$ & $8.5-20.8$ & $-18.0 \pm 0.9$ & $-18.7--16.8$ & 4 & $9.9 \pm 3.2$ & $7.0-12.8$ & $-18.2 \pm 0.4$ & $-18.6--17.7$ & 4 & $7.4 \pm 0.8$ & $6.5-8.2$ & $-19.8 \pm 1.5$ & $-22.0--18.7$ \\
\hline & Tuna larvae & 0 & - & - & - & - & 0 & - & - & - & - & 3 & $5.0 \pm 1.3$ & $3.7-6.3$ & $-18.1 \pm 0.6$ & $-18.8--17.6$ \\
\hline & Fish larvae & 3 & $10.6 \pm 3.0$ & $7.2-12.6$ & $-18.5 \pm 0.9$ & $-19.5--17.6$ & 7 & $7.5 \pm 2.0$ & $5.2-10.8$ & $-18.3 \pm 1.0$ & $-20.5--17.4$ & 6 & $4.9 \pm 1.8$ & $2.7-7.2$ & $-19.0 \pm 0.9$ & $-20.7--18.3$ \\
\hline \multicolumn{17}{|l|}{ Crustaceans } \\
\hline \multirow{8}{*}{ Calanoida } & Metridia venusta & 3 & $12.2 \pm 2.5$ & $9.5-14.5$ & $-19.7 \pm 0.5$ & $-20.3--19.3$ & 3 & $9.0 \pm 1.2$ & $8.0-10.4$ & $-19.6 \pm 0.2$ & $-19.8--19.5$ & 3 & $6.6 \pm 0.5$ & $6.1-7.1$ & $-20.1 \pm 0.6$ & $-20.6--19.4$ \\
\hline & $\begin{array}{l}\text { Pleuromamma } \\
\text { abdominalis }\end{array}$ & 3 & $12.7 \pm 2.0$ & $10.4-14.3$ & $-20.6 \pm 1.0$ & $-21.7--19.8$ & 4 & $8.4 \pm 2.5$ & $5.7-11.1$ & $-20.1 \pm 0.3$ & $-20.4--19.8$ & 3 & $6.6 \pm 0.8$ & $5.9-7.5$ & $-21.1 \pm 0.6$ & $-21.8--20.7$ \\
\hline & $\begin{array}{l}\text { Pleuromamma } \\
\text { xiphias }\end{array}$ & 3 & $12.6 \pm 1.7$ & 10.7-13.9 & $-21.5 \pm 1.1$ & $-22.4--20.2$ & 3 & $8.8 \pm 3.0$ & $6.2-12.1$ & $-20.7 \pm 0.5$ & $-21.3--20.4$ & 3 & $6.3 \pm 1.5$ & $5.0-7.9$ & $-22.2 \pm 1.6$ & $-23.3--20.3$ \\
\hline & Candacia sp. & 2 & $9.1 \pm 3.5$ & $6.7-11.6$ & $-19.6 \pm 0.1$ & $-19.7--19.5$ & 3 & $7.8 \pm 1.9$ & $6.1-9.8$ & $-19.1 \pm 0.5$ & $-19.5--18.6$ & 3 & $4.8 \pm 1.2$ & $3.8-6.1$ & $-20.7 \pm 0.7$ & $-21.5--20.3$ \\
\hline & Temora sp. & 0 & - & - & & - & 1 & 7.9 & - & -18.1 & - & 1 & 2.7 & - & -19.7 & - \\
\hline & Anomalocera sp. & 1 & 7.4 & - & -19.0 & - & 0 & - & - & - & - & 0 & - & - & - & - \\
\hline & $\begin{array}{l}\text { Unidentified } \\
\text { Calanoida }\end{array}$ & 4 & $13.2 \pm 2.0$ & $11.3-15.2$ & $-20.3 \pm 1.0$ & $-21.2--18.9$ & 3 & $9.7 \pm 3.2$ & $6.0-12.0$ & $-19.8 \pm 0.5$ & $-20.2--19.2$ & 3 & $7.0 \pm 1.7$ & $5.4-8.7$ & $-20.2 \pm 0.5$ & $-20.6--19.7$ \\
\hline & $\begin{array}{l}\text { Euphausiidae } \\
\text { (>10 mm) }\end{array}$ & 4 & $10.9 \pm 3.4$ & $8.6-15.9$ & $-18.5 \pm 0.3$ & $-18.8--18.1$ & 5 & $7.9 \pm 2.0$ & $5.8-11.3$ & $-18.9 \pm 0.6$ & $-19.8--18.5$ & 4 & $7.2 \pm 1.2$ & $6.2-8.8$ & $-20.2 \pm 0.7$ & $-21.1--19.6$ \\
\hline Euphausiace & $\begin{array}{l}\text { Euphausiidae } \\
\text { (<10 mm) }\end{array}$ & 4 & $11.3 \pm 3.7$ & $7.0-15.8$ & $-19.0 \pm 0.4$ & $-19.5--18.6$ & 5 & $7.8 \pm 2.6$ & $4.8-10.8$ & $-19.2 \pm 0.9$ & $-20.3--18.3$ & 4 & $5.6 \pm 1.1$ & $4.6-6.7$ & $-20.1 \pm 0.7$ & $-21.0--19.4$ \\
\hline \multicolumn{17}{|l|}{ Cyanobacteria } \\
\hline & Trichodesmium sp. & 0 & - & - & - & - & 0 & - & - & - & - & 2 & $0.5 \pm 0.4$ & $0.3-0.8$ & $-14.6 \pm 3.4$ & $-17.0--12.2$ \\
\hline \multicolumn{17}{|l|}{ POM } \\
\hline & Surface & 5 & $5.8 \pm 1.7$ & $4.2-7.8$ & $-23.2 \pm 0.4$ & $-23.7--22.7$ & 7 & $4.6 \pm 1.4$ & $2.9-6.7$ & $-24.1 \pm 0.7$ & $-24.9--23.0$ & 4 & $1.6 \pm 1.5$ & $-0.04-3.3$ & $-23.8 \pm 0.9$ & $-24.7--23.0$ \\
\hline & $\begin{array}{l}\text { Maximum } \\
\text { fluorescence }\end{array}$ & 5 & $5.1 \pm 1.8$ & $2.5-7.2$ & $-26.0 \pm 0.8$ & $-27.0--25.4$ & 6 & $5.2 \pm 1.3$ & $2.8-6.6$ & $-26.2 \pm 0.4$ & $-26.8--25.8$ & 3 & $2.9 \pm 1.4$ & $1.3-3.8$ & $-26.0 \pm 0.5$ & $-26.5--25.4$ \\
\hline & Deep & 5 & $9.9 \pm 2.4$ & $5.8-12.1$ & $-26.2 \pm 0.8$ & $-27.3--25.1$ & 6 & $9.0 \pm 1.2$ & $7.4-10.7$ & $-25.9 \pm 0.7$ & $-27.1--25.5$ & 4 & $6.9 \pm 1.4$ & 5.3-8.7 & $-25.1 \pm 0.3$ & $-25.4--24.7$ \\
\hline
\end{tabular}


Manuscript: Microbial functional structure and stable isotopic variation of leptocephali across three current zones in the western South Pacific (Revision requested for PROOCE_2019_94)

Declaration of interests

$\bigotimes$ The authors declare that they have no known competing financial interests or personal relationships that could have appeared to influence the work reported in this paper.

$\square$ The authors declare the following financial interests/personal relationships which may be considered as potential competing interests:

Christine Dupuy

$03 / 10 / 2019$

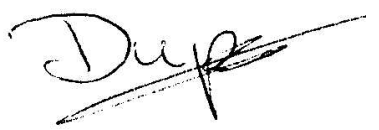




\section{Highlights}

- Western South Pacific microbial biomass/function and stable isotopes were examined

- Primary producers, whatever the depth, were N-P co-limited

- All zones were based on a heterotrophic planktonic functioning

- Stable isotope signatures of leptocephali, POM and other components of the food web were analyzed

- POM signatures varied with depth and latitude, influencing all taxonomic groups

- The presence of Trichodesmium may contribute to low southern $\delta^{15} \mathrm{~N}$ values 